\title{
VITAMIN A AND CAROTENOIDS IN CERTAIN INVERTEBRATES. I. MARINE CRUSTACEA
}

\author{
By L. R. Fisher, S. K. Kon and S. Y. Thompson \\ National Institute for Research in Dairying, University of Reading
}

(Text-figs. I-6)

\begin{tabular}{|c|c|c|c|c|c|c|c|}
\hline \multicolumn{8}{|c|}{ CONTENTS } \\
\hline & & & & & & & \\
\hline Introduction & & & & . & . & . & 229 \\
\hline Material and $\mathrm{n}$ & met & ods of coll & ction & & . & . & $23 \mathrm{I}$ \\
\hline Chemical and & phy & ical tests & . & . & . & . & 232 \\
\hline Met & . &.$\quad$. & . & . & . & . & 232 \\
\hline Rest & . & . & . & . & & . & 235 \\
\hline Biological test: & & . & . & . & ra & . & 247 \\
\hline Metl & . & . & . & . & . & . & 247 \\
\hline Results & . & . & . & . & & . & 250 \\
\hline iscussion & . & . & . & . & & & 252 \\
\hline Summ & . & . & . & . & & . & 256 \\
\hline References & . & . & . & . & . & . & 256 \\
\hline
\end{tabular}

\section{INTRODUCTION}

It has for long been accepted that carotene is converted in the liver to vitamin $\mathrm{A}$, but recent work has established that, in several mammalian species at any rate, the conversion takes place in the small intestine (see, for example, the recent review by Kon \& Thompson, I95I).

During the study of the conversion of $\beta$-carotene to vitamin A in the intestine of rats and pigs (Thompson, Ganguly \& Kon, 1947, 1949), Prof. B. C. P. Jansen of Amsterdam drew our attention to the work of Wagner (1939), who claimed to have observed the phenomenon in the intestine of blue and fin whales at the Lopra Whaling Station in the Faeroes and stated that they derived the $\beta$-carotene from krill ('Gattung der Euphausia superba Dana'). E. superba Dana is exclusively antarctic, so that the krill which Wagner examined must have been composed of other Crustacea, of which the most likely species in the krill of Faeroese waters is Meganyctiphanes norvegica (M. Sars). Wagner claimed that in his krill $\beta$-carotene was present to the extent of $14.5 \mathrm{mg}$. $/ \mathrm{kg}$. This was suprising, since astaxanthin is the characteristic carotenoid pigment of Crustacea and the presence of such relatively enormous quantities of $\beta$-carotene did not seem likely.

Thompson et al. (1949) obtained, therefore, through the courtesy of Dr Robinson of the whaling factory ship Balaena, samples of food from the stomachs and intestines, and portions of the intestinal wall, of two antarctic 
fin whales. The krill from these whales was identified as Euphausia superba Dana. It contained large quantities of astaxanthin but only small traces of $\beta$-carotene. Preformed vitamin A, identified, after chromatography, by the antimony-trichloride test, absorption at $328 \mathrm{~m} \mu$, behaviour on mixed chromatography with pure vitamin $\mathrm{A}$ and liver-storage tests with rats depleted of vitamin A, was present, however, in appreciable amounts, in one of the whales to the extent of about $6 \mathrm{i} . \mathrm{u}$./g. stomach contents, with smaller concentrations farther along the intestine. Astaxanthin occurred in the intestinal contents in increasing concentration along the gut; no carotene was detected (Kon \& Thompson, I949a).

In northern waters, the main food supply of blue and fin whales is derived from the euphausiids, Meganyctiphanes norvegica and Thysanoessa inermis Krøyer (Einarsson, I945). With the kind help of the workers at the Millport Marine Station, Kon \& Thompson (I949b) got from Loch Fyne specimens of Meganyctiphanes norvegica and of Thysanoessa raschii (M. Sars), closely related to T. inermis, and found much larger quantities of vitamin A than in other Eucarida caught there simultaneously.

The occurrence of vitamin A or its precursors in marine invertebrates has been studied by others since Hjort (I922), by biological tests with rats, detected vitamin A activity in extracts from some marine plants and animals, including Crangon sp. and Pandalus borealis. The evidence; however, is fragmentary and often conflicting; in several instances the total vitamin A activity was measured biologically, leaving undecided the presence of preformed vitamin $\mathrm{A}$.

Drummond \& Hilditch (I930) reported that copepods, Nephrops norvegicus, and Meganyctiphanes norvegica contained little or no vitamin A.

Drummond \& Gunther (1930, I934), studying fatty constituents of marine plankton, looked for vitamin A but concluded that 'vitamin A as such is apparently absent from both phytoplankton and zooplankton'. The statement was based for phytoplankton on an examination of oils isolated from the diatoms Chaetoceras spp. and Lauderia borealis, and for zooplankton on a similar study of mixed copepods and Calanus finmarchicus (Collin, Drummond, Hilditch \& Gunther, 1934). In Calanus caught at the end of May off the north coast of Norway, Lederer (1938) found no trace of vitamin A. Drummond \& MacWalter (I935) examined oil from antarctic krill (which consisted mainly of Euphausia sp.), but did not look specifically for vitamin A. Extracts of the non-saponifiable portion contained a pigment which gave a slightly blue-green colour with antimony trichloride. They pointed out, with reference to earlier work based on biological tests, that certain isomeric forms of carotene, among the naturally occurring lipochromes, are converted into vitamin A by the rat. Gillam, El Ridi \& Wimpenny (I939) studied by chemical and physical methods the seasonal variation of vitamin A in gross plankton samples from the North Sea; the highest content of vitamin A 
coincided with the first phytoplankton maximum and the zooplankton breeding period, diminishing later in the year.

Pugsley (I94I) found vitamin A to the extent of 600 i.u./g. in oil extracted from the viscera of tinned crabs (Cancer magister); the oil constituted $6 \%$ of the weight of these tissues.

The retina of the squid, Loligo pealii, contains $\mathrm{I}-2 \mu \mathrm{g}$. of vitamin $\mathrm{A}_{1}$ (Wald, I94I) and about three times this amount of retinene ${ }_{1}$, and no trace of these or other carotenoids was found in other squid tissues, but the eyes of the crabs Uca pugnax and Carcinus maenas and those of the lobster (unspecified) contain high concentrations of vitamin $\mathrm{A}_{1}$, but no retinene. In the squid vitamin A remains constant in all conditions of light and darkness and does not, therefore, appear to participate directly in the visual processes. Wald (I943) also found vitamin $A_{1}$, retinene ${ }_{1}$ and astaxanthin in the eyes of the fresh-water crayfish, Cambarus virilis. Neilands (I947) studied the conversion of carotene to vitamin $\mathrm{A}$ in the lobster, Homarus americanus, and found $36 \mathrm{i.u.} / \mathrm{g}$. in the hepatopancreas and roo i.u./g. in the eyes on a carotenefree diet, and 53 i.u./g. in the hepatopancreas and I83 i.u./g. in the eyes on a diet supplemented with $\beta$-carotene.

Recent developments in the micro-analysis of vitamin $\mathrm{A}$ in the presence of a large excess of carotenoids made it possible to undertake a more detailed and systematic study than those hitherto attempted. The present paper is partly concerned with work on krill outlined above and in subsequent studies published only in abstract (Batham, Fisher, Henry, Kon \& Thompson, I95I; Fisher, Kon \& Thompson, I95I) and partly with work on other species and on geographical, developmental and seasonal variations and anatomical distribution of vitamin $\mathrm{A}$ in those animals found to possess it.

\section{Material and Methods of Collection}

The material consisted of plankton collected in Loch Fyne, the FaeroeShetland area and north-west of the coast of Norway; krill obtained from whales in arctic and antarctic waters, and littoral and benthic animals from Loch Fyne and the Essex coast.

Regular visits were made to the Marine Station, Millport, at monthly, or slightly less frequent, intervals, and the principal species obtained were Meganyctiphanes norvegica (M. Sars), Thysanoessa raschii (M. Sars), Euchaeta norvegica Boeck, Calanus finmarchicus (Gunnerus), Crangon allmani Kinahan, Pandalus bonnieri Caullery and Nephrops norvegicus L. The Faeroe-Shetland area was visited in the Scottish Home Department's Fisheries Research Vessel Scotia during November 1950, and Meganyctiphanes norvegica and Thysanoessa inermis Krøyer were the most important animals brought back from these waters. Antarctic krill was kindly supplied from the W.F.S. Balaena, and arctic specimens were taken from a fin whale caught 200 miles 
north-north-west of Bergen and also free-swimming from the same area, in June 1950, by catcher Hval 2 from Blomvåg Hvalstasjon, Norway, and from a blue whale caught 40 miles north-west of St Kilda by a catcher from the whaling station of Scottish Whalers Limited, West Loch, Tarbert, Harris. Littoral and benthic Crustacea were collected at Burnham-on-Crouch and other parts of the Essex coast and included Carcinus maenas (Pennant), Eupagurus bernhardus (L.) and Gammarus marinus Leach.

Initially specimens were placed as soon as possible after catching in a measured volume of absolute alcohol, after drying with filter paper. Aluminium containers were used for lightness, chemical inertness and opacity. Alcohol is an excellent preservative for vitamin A and carotenoids, but, since it leaches them out, distribution in the various organs cannot be studied and only the total content can be measured. Later it was found more convenient and accurate to place specimens, immediately after catching, for a minute or so in boiling sea water. Boiling fixes vitamin A and carotenoids in their original sites and anatomical separation is later possible. As shown below, the method also allows more accurate weighing of the specimens. The specimens thus treated were transported in aluminium containers without preservative and kept as cool as possible. The greatest attention was always paid to protection from strong light, in order to reduce photochemical effects.

\section{Chemical and Physical Tests}

\section{Weighing of Specimens}

\section{Methods}

The weight of the alcohol-preserved specimens was determined by weighing the containers full and again empty. The volume of absolute alcohol being known, the weight of the animals or tissues could be calculated, but indirect weighing was not accurate enough with small animals or parts of animals.

Table I. Recovery of Oil, Vitamin A and Carotenoids from Specimens of MEGANYCTIPHANES NORVEGICA PRESERVED BY AlCOHOL (A) OR BY BRIEF BOILING IN SEA-WATER (B)

$\begin{array}{cccccc}\begin{array}{c}\text { Preserved } \\ \text { by }\end{array} & \begin{array}{c}\text { Length } \\ (\mathrm{cm} .)\end{array} & \begin{array}{c}\text { No. of } \\ \text { specimens }\end{array} & \begin{array}{c}\text { Oil } \\ (\mathrm{mg} \cdot / \text { specimen) }\end{array} & \begin{array}{c}\text { Vitamin A } \\ (\text { i.u./specimen })\end{array} & \begin{array}{c}\text { Astaxanthin } \\ (\mu \mathrm{g} . / \text { specimen })\end{array} \\ \text { A } & <3 & 238 & 3 & \mathrm{r} \cdot 2 & 4 \cdot 5 \\ \text { B } & <3 & 93 & 3 & 1 \cdot 3 & 4 \cdot 8 \\ \text { A } & 3-4 & 95 & 18 & 4 \cdot 2 & 16 \\ \text { B } & 3-4 & 60 & 20 & 5 \cdot 4 & 23 \\ \text { A } & >4 & 44 & 44 & 27 & 44 \\ \text { B } & >4 & 20 & 39 & 26 & 44\end{array}$

Comparison of alcohol-preserving with boiling showed equal recovery of vitamin A and carotenoids by both methods (Table I). As a further check the right eye of each of a group of I 50 Meganyctiphanes norvegica, all of average length greater than $40 \mathrm{~mm}$., was removed and preserved in alcohol. The 
animals were then boiled and the left eyes were removed. The two lots of eyes were analysed separately with the following results:

$\begin{array}{lcc} & \text { Vitamin A } & \text { Carotenoids } \\ & \text { (i.u./eye) } & (\mu \mathrm{g} \text {./eye }) \\ \text { Eyes preserved in alcohol } & \text { IO.9 } & 4 \cdot 7 \\ \text { Eyes boiled } & \text { II. } 7 & 5 \cdot 0\end{array}$

The water in which the specimens had been boiled was examined and no trace of vitamin A or carotenoids was found in it.

To determine the effect of boiling on the weight of the animals, ten $M$. norvegica were weighed alive after removal of surplus moisture, and ten after boiling; they were then dried at $105^{\circ} \mathrm{C}$. for $20 \mathrm{hr}$. The effect of boiling was negligible, since the live lost $69 \%$ and the boiled $72 \%$ of their weight on drying.

After any necessary dissection had been completed in red light, boiled specimens or parts of them were weighed and preserved in alcohol.

\section{Extraction of Lipids, Vitamin A and Carotenoids and Measurement of Total Carotenoids}

This was done as described by Thompson et al. (I949). Specimens were macerated in a Waring Blendor jar, proportions taken for each homogenization being about $20 \mathrm{~g}$. of tissue, $60 \mathrm{ml}$. absolute alcohol and $200 \mathrm{ml}$. light petroleum (b.p. $40-60^{\circ}$ C.). Before maceration, nitrogen was bubbled through the mixture and into the mouth of the jar which was then closed with a lid. The mixture was homogenized for about $2 \mathrm{~min}$., transferred to a separating funnel and the bottom layer was run off and re-extracted with a further $200 \mathrm{ml}$. of light petroleum. The two extracts were combined, the volume determined and the total carotenoids measured in the photoelectric spectrophotometer of Thompson (I949) at $45 \mathrm{I} \mathrm{m} \mu$, that is, at the absorption maximum for $\beta$-carotene. For animals whose only carotenoid was astaxanthin this reading was used as a measure of the pigment. Values obtained by this means were probably some Io \% lower than those based on the measurement of astaxanthin at its absorption maximum and referred to the extinction for the pure substance.

The solvent was evaporated and the oil weighed and dissolved in $n$-hexane.

\section{Separation of Vitamin A from $\beta$-Carotene and other Carotenoids}

The chromatographic method of Thompson et al. (I949), employing alumina columns, was used. The separation and measurement of vitamin A, total carotenoids and $\beta$-carotene is shown schematically in Fig. I. Two alternatives could be followed: (a) direct saponification of the extract in $n$-hexane and subsequent chromatography on aluminium oxide; $(b)$ direct chromatography of the extract which separated vitamin A ester and alcohol. In $(b)$, the two fractions were saponified and rechromatographed to obtain 
a further purification from carotenoids of the vitamin A, now in the alcohol form. Method (a) was used for routine work where a separation of the two

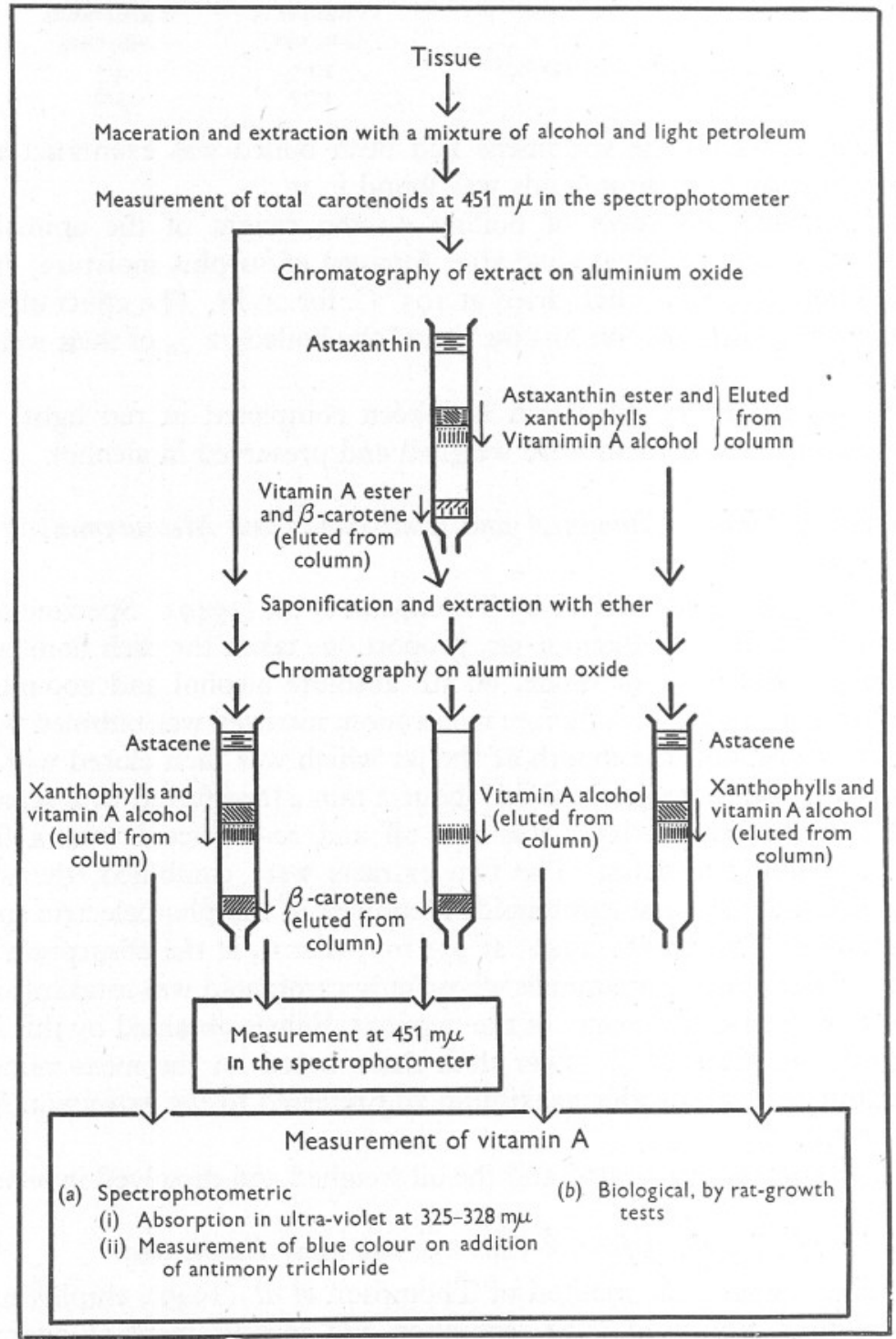

Fig. I. Outline of methods of separation and measurement of vitamin A, astaxanthin and $\beta$-carotene in marine animals.

forms was not required and the pigments were such that they did not contaminate the vitamin A fraction. $\beta$-Carotene, if present, was separated by either method and collected at the stages indicated in the figure. 
Astaxanthin and xanthophyllic pigments, if present, were not, as a routine procedure, measured after chromatography. It will be noticed from the figure that we were unable to separate xanthophylls from vitamin A alcohol. Where these pigments were present in relatively large quantities they vitiated the determination of vitamin A in this form. The difficulty did not arise with euphausiids and was probably of little consequence with the other Crustacea.

The fractions containing vitamin A were taken up in $\mathrm{I} \cdot 5 \mathrm{ml}$. chloroform and that containing $\beta$-carotene in $5 \mathrm{ml} . n$-hexane. Vitamin A was measured by the antimony-trichloride reaction, and $\beta$-carotene determined on the photoelectric spectrophotometer as described by Thompson (1949) and Thompson et al. (1949). Absorption curves for vitamin A in ultra-violet and for $\beta$-carotene and astaxanthin in ultra-violet and visible light were obtained on the Beckman quartz photoelectric spectrophotometer.

For euphausiids, the following procedure was adopted for the identification of astaxanthin and its ester. The absorption curve of the total extract in $n$-hexane was determined. The pigment was further identified by its behaviour on chromatography (Goodwin \& Srisukh, 1949) and its low solubility in diethyl ether after saponification.

\section{Results}

\section{The Form of Vitamin $A$ in the Crustacea}

As stated above (p. 234) vitamin A ester and alcohol were not always separated in routine tests, and for a number of species only values for total vitamin A are at present available. Our observations on Euphausiacea and certain Decapoda show that in them vitamin A was present mainly as the ester. Details are given in the sections dealing with the relevant species.

Table II. Vitamin A and Carotenoids per gram in Gut Contents of Antarctic Fin Whales (Nos. I and 2) and of Blue Whale (No. 3)

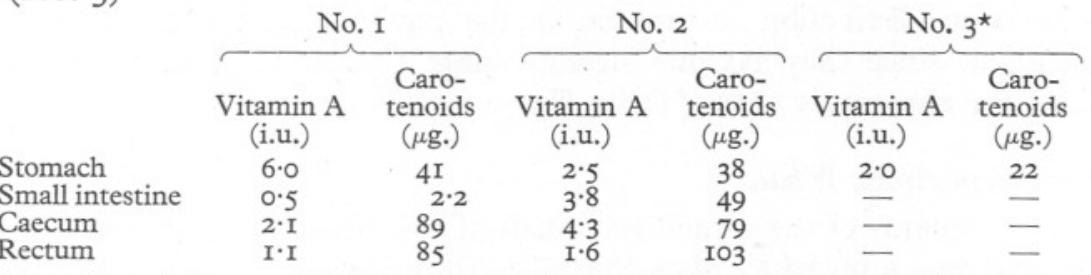
oil.

* No. 3, blue whale, stomach oil 2.I \%, vitamin A 9r i.u./g. oil and carotenoids I.02 mg./g.

\section{Krill from Antarctic Whales}

Contents of the alimentary canals of two fin whales and one blue whale were examined. They had been preserved by deep-freezing, and were identified by Prof. C. H. O'Donoghue as being mainly Euphausia superba Dana. Results obtained are shown in Table II. 
The lower value obtained for the stomach contents of fin whale 2 was possibly correlated with their greater fluidity. They were either in a more advanced stage of digestion or contained less krill in proportion to the digestive juices. Judging from the appearance of the material the former explanation was more likely. In the light of later work (see p. 239), it is also possible that the difference in concentration of vitamin A was due to differences in the developmental stage and size of the krill eaten by the two fin whales. Vitamin A was present mainly in the ester form.

So far no free swimming $E$. superba has been available to us for an examination of its contents of vitamin A and carotenoids.

\section{Organs of Antarctic Whales}

Segments of the alimentary canals of the two fin whales whose stomach contents were analysed were also examined, along with organs from three blue whales, and the results obtained are shown in Table III. The gradient of vitamin A decreased from the small intestine to the rectum, in agreement with our findings on the absorption of vitamin A in other mammals (Thompson et al. 1949). It seems possible that the absorption of vitamin A is incomplete as it was still found in the caecal and rectal contents.

\section{Table III. Vitamin A Content (I.U./G.) IN ANTARctic Fin AND Blue Whales}

\begin{tabular}{|c|c|c|}
\hline $\begin{array}{l}\text { Small intestine: Mucosa } \\
\text { Wall }\end{array}$ & $\begin{array}{c}\text { Fin no. I } \\
0.34^{\star} \\
0.21\end{array}$ & $\begin{array}{c}\text { Fin no. }{ }^{2} \\
0.64 t \\
0.29\end{array}$ \\
\hline Caecum & 0.12 & 0.26 \\
\hline Rectum & 0.19 & $0.2 \mathrm{I}$ \\
\hline
\end{tabular}

Blue whale No. I ( $83 \mathrm{ft}$. lactating), liver 6300 ; No. 2 ( $88 \mathrm{ft}$. lactating), liver $6 \mathrm{I} 20$; No. 3 (87 ft.), kidney $3 \cdot 6$.

In contradistinction to vitamin $\mathrm{A}$ the pigments did not appear to be absorbed, since they became steadily more concentrated in their passage along the alimentary canal (Table II).

\section{Krill from Arctic Whales}

The contents of the alimentary canals of two whales were examined. One of these was a fin whale shot 200 miles from the coast of Norway and the other was a blue whale shot 40 miles north-west of St Kilda. The results are shown in Table IV. In both instances the krill was identified as Meganyctiphanes norvegica (M. Sars).

The low figures for vitamin A and astaxanthin in the mouth contents of the blue whale were probably due to considerable leaching out by sea water while the whale was being towed 80 miles back to the whaling station at Tarbert. The krill in the mouth was much paler in colour than that collected 
from farther along the gut. In the stomach of the blue whale, the euphausiids had undergone little digestion and individual animals were still distinguishable. The presence of krill in the mouth and oesophagus indicates possible regurgitation, which also may have taken place between the four parts of the stomach, as happens when a whale is shot. Unfortunately, no information is available to indicate from which part of the stomach the contents were taken in any of the whales, either arctic or antarctic, examined.

TABle IV. OIl PER CENT, Vitamin A ANd Carotenoids PER GRAM In the Gut Contents of ARCTic Whales

\begin{tabular}{|c|c|c|c|c|c|c|}
\hline & \multirow{2}{*}{$\begin{array}{c}\text { Oil } \\
(\%)\end{array}$} & \multicolumn{2}{|c|}{ Vitamin A } & \multicolumn{2}{|c|}{ Astaxanthin } & \multirow[b]{2}{*}{$\beta$-Carotene } \\
\hline & & (i.u./g.) & (i.u./g. oil) & $(\mu \mathrm{g} \cdot / \mathrm{g})$. & (mg./g. oil) & \\
\hline \multicolumn{7}{|c|}{ Fin whale, II. vi. 50, off Norway } \\
\hline Stomach & 0.8 & I.5 & I 88 & 22 & $2.8 \mathrm{I}$ & Trace \\
\hline Small intestine & $O \cdot I$ & $2 \cdot 5$ & 2380 & $5 \cdot 0$ & $4 \cdot 80$ & Trace \\
\hline \multicolumn{7}{|c|}{ Blue whale, 22. viii. 50, 40 miles north-west of St Kilda } \\
\hline Mouth & 0.7 & 0.5 & 87 & $\mathrm{I} \cdot 6$ & 0.24 & None \\
\hline Oesophagus & 0.1 & $3 \cdot \mathrm{I}$ & 325 & 46 & $4 \cdot 79$ & None \\
\hline Stomach & 0.1 & $5 \cdot 0$ & 392 & 48 & 3.78 & Trace \\
\hline
\end{tabular}

Table V. Oil per cent, Vitamin A ANd Carotenoids Per gram in FreE-SWIMMING MEGANYCTIPHANES NORVEGICA (M. SARS)

\begin{tabular}{|c|c|c|c|c|c|c|}
\hline & Date & Oil & Vitar & $\underbrace{}_{\min A}$ & $\begin{array}{l}\text { Astax- } \\
\text { anthin }\end{array}$ & \\
\hline Locality & (I950) & $(\%)$ & (i.u./g.) & (i.u./g. oil) & ( $\mu$ g. $/ \mathrm{g})$. & $\beta$-Carotene \\
\hline Loch Fyne & I8. viii๋ & $2 \cdot 2$ & I5 & 680 & 42 & Faint trace \\
\hline Loch Fyne & 4. i & $3 \cdot I$ & 26 & 835 & 70 & Trace \\
\hline $\begin{array}{l}\text { North Sea } \\
\left(63^{\circ} 20^{\prime} \text { N., } 0^{\circ} 30^{\prime} \text { E.) }\right.\end{array}$ & 30. vi & $5 \cdot 3$ & I5 & 288 & 46 & None \\
\hline Loch Fyne & I7. viii & $6 \cdot 7$ & 40 & 596 & II 2 & Trace \\
\hline $\begin{array}{l}\text { Sandy Bank, Faeroes } \\
\left(6 \mathrm{I}^{\circ} 54^{\prime} \text { N., } 5^{\circ} 45^{\prime} \text { W. }\right)\end{array}$ & 6. xi & $5 \cdot 6$ & I9 & 343 & 57 & None \\
\hline
\end{tabular}

\section{Free-swimming Arctic Krill}

Meganyctiphanes norvegica. The most important species of euphausiid in arctic krill, forming the food of baleen whales, is Meganyctiphanes norvegica, and, in order to obtain results comparable with those from animals taken from whales, free-swimming animals from different areas of the sea were examined. The work of Macdonald (1927) on this species in Loch Fyne indicated that this sea-loch was a good and convenient source of supply. Other samples of arctic krill were got from the Norwegian whaling area and from the Sandy Bank area, near the Faeroes. Table V shows the results of analyses of these specimens. Of the vitamin A, 94\% was in the ester form and was chromatographically homogeneous before saponification with pure vitamin A acetate and after saponification with vitamin A alcohol prepared from the acetate by saponification. The chromatographic homogeneity was observed by fluorescence under ultra-violet light. 
The Loch Fyne specimens were caught at depths of I2O-I40 m., about $20 \mathrm{~m}$. from the bottom in a I m. stramin net. Those from the Norwegian whaling ground were taken from the surface of the sea in daylight. The haul in the Sandy Bank waters was made with a I m. coarse silk net at II p.m. at a depth of $20 \mathrm{~m}$., where the sounding was $274 \mathrm{~m}$.

The much higher concentration of vitamin A in the free-swimming animals than that in those from the whales is very striking, but we noted that the average overall length of specimens taken from the blue whale at Tarbert was only about $30 \mathrm{~mm}$., whereas those caught in Loch Fyne were over $35 \mathrm{~mm}$. in length. It was necessary, therefore, to investigate any possible relationship between size and vitamin A concentration. Conditions of sorting specimens on the ship where large numbers had to be dealt with as quickly as possible rendered the best means of size-grouping, i.e. weighing, impossible of

Table VI. Relationship Between Oil Per Cent, Vitamin A and CAROTENOIDS PER GRAM AND LENGTH AND WeIGHT IN MEGANYCTIPHANES NORVEGICA (M. SARS)

\begin{tabular}{|c|c|c|c|c|c|c|c|}
\hline \multirow[b]{3}{*}{ Date } & \multicolumn{6}{|c|}{ ( $\beta$-Carotene absent) } & \multirow{3}{*}{$\begin{array}{l}\text { Astaxanthir } \\
(\mu \mathrm{g} . / \mathrm{g} .)\end{array}$} \\
\hline & \multirow{2}{*}{$\begin{array}{l}\text { Length } \\
\text { overall } \\
\text { (cm.) }\end{array}$} & \multirow{2}{*}{$\begin{array}{c}\text { No. of } \\
\text { specimens }\end{array}$} & \multirow{2}{*}{$\begin{array}{c}\text { Mean } \\
\text { wt. } \\
\text { (mg.) }\end{array}$} & \multirow{2}{*}{$\begin{array}{l}\text { Oil } \\
(\%)\end{array}$} & \multicolumn{2}{|c|}{ Vitamin A } & \\
\hline & & & & & (i.u./g.) & (i.u./g. oil) & \\
\hline 4. x. 50 & $<3$ & 76 & 68 & $\mathrm{I} \cdot 7$ & $9 \cdot 6$ & 555 & 78 \\
\hline 4. x. 50 & $3-4$ & I3I & 320 & IO. I & I3 & I3I & 55 \\
\hline 4. x. 50 & $>4$ & 53 & 500 & $8 \cdot 6$ & 34 & 397 & 60 \\
\hline 2 I. xi. 50 & $<3$ & 93 & 85 & $3 \cdot 2$ & I5 & 466 & 56 \\
\hline 2 I. xi. 50 & $3-4$ & 60 & 380 & $6 \cdot 0$ & 16 & 263 & 68 \\
\hline 21. xi. 50 & $>4$ & 20 & 580 & $6 \cdot 7$ & 44 & 660 & 75 \\
\hline I0. i. $5 \mathrm{I}$ & $<3$ & 3424 & 90 & $2 \cdot 9$ & 21 & 717 & 66 \\
\hline Io. i. $5 \mathrm{I}$ & $3-4$ & I072 & 330 & 4.9 & 24 & 475 & 63 \\
\hline Io. i. $5 \mathrm{I}$ & $>4$ & I40 & 570 & $6 \cdot 5$ & 43 & 666 & 83 \\
\hline
\end{tabular}

application, and so overall length was taken as a criterion. In the initial experiments, three size-groups of specimens taken in Loch Fyne from hauls by the M.V. Calanus were examined, those animals less than $30 \mathrm{~mm}$. long, those between 30 and $40 \mathrm{~mm}$., and those over $40 \mathrm{~mm}$. Each group was weighed in order to determine the average weight of individual members. The results of these experiments are shown in Table VI.

The concentration of vitamin A, even in the smallest of the size-groups, was still much higher than the highest obtained for Meganyctiphanes from the whale, even though the average size of these was greater.

The noteworthy feature of the table is the marked increase in the vitamin A content with size. At each examination the concentration was about the same in the two smaller groups but was more than doubled in the largest. The content of astaxanthin also increased, but the increase in concentration in the largest groups was much less marked than for vitamin $\mathrm{A}$. $\beta$-Carotene was not present in sufficient quantity to be detected. 
To determine more precisely the relationship between vitamin A content and size, grouping of sizes was carried out in greater detail as a result of practice and experience. On I4-I5 February I95I, a series was obtained with a size interval of $2 \mathrm{~mm}$. Macdonald's (I927) method of measuring the length from the tip of the rostrum to the base of the telson was also adopted at this stage, in preference to using the overall length as previously. These groups were weighed and analysed as before, and Table VII shows the results obtained. The vitamin A content per specimen increased at first gradually, but the increase became disproportionately great in the larger size-groups, and the concentration, which was fairly constant in the smaller animals, showed an upward trend in the last four groups. Astaxanthin increased steadily in content with the size of the animal without any clear-cut change in the concentration.

Table VII. Relationship between OIL PeR CENT, Vitamin A AND CAROTENOIDS PER GRAM AND LENGTH AND WEIGHT IN MEGANYCTIPHANES NORVEGICA (M. SARS), TAKEN ON I4-I5 FEBRUARY I95I, IN LOCH FYNE

\begin{tabular}{|c|c|c|c|c|c|c|}
\hline \multicolumn{7}{|c|}{$n t$ ) } \\
\hline \multirow{2}{*}{$\begin{array}{l}\text { No. of } \\
\text { specimens }\end{array}$} & \multirow{2}{*}{$\begin{array}{l}\text { Length* } \\
\text { (mm.) }\end{array}$} & \multirow{2}{*}{$\begin{array}{c}\text { Mean } \\
\text { wt. } \\
\text { (mg.) }\end{array}$} & \multirow{2}{*}{$\begin{array}{l}\text { Oil } \\
(\%)\end{array}$} & \multicolumn{2}{|c|}{ Vitamin A } & \multirow{2}{*}{$\begin{array}{c}\text { Astaxanthin } \\
(\mu \mathrm{g} . / \mathrm{g} .)\end{array}$} \\
\hline & & & & (i.u./g.) & (i.u./g. oil) & \\
\hline I2 & I7 & 45 & 4.9 & 22 & 455 & 88 \\
\hline 43 & 19 & 70 & $2 \cdot 2$ & I7 & 759 & 60 \\
\hline 47 & $2 I$ & 94 & $\mathrm{I} \cdot 8$ & I3 & 700 & 57 \\
\hline 32 & 23 & II 5 & I. 7 & 20 & II7I & $5 \mathrm{I}$ \\
\hline 25 & 25 & I55 & $2 \cdot 4$ & $2 \mathrm{I}$ & 858 & 54 \\
\hline 49 & 27 & 209 & $2 \cdot 0$ & $2 \mathrm{I}$ & 1035 & 53 \\
\hline II6 & 29 & 265 & $3 \cdot I$ & I6 & 529 & $5 \mathrm{I}$ \\
\hline 207 & $3 I$ & 312 & 3.4 & I8 & 524 & 54 \\
\hline I 23 & 33 & 394 & 3.6 & 22 & 603 & $5 \mathrm{I}$ \\
\hline I 34 & 35 & 469 & 4.6 & 32 & 704 & 72 \\
\hline IO2 & 37 & 513 & $5 \cdot 6$ & 50 & 895 & 75 \\
\hline 37 & 39 & 636 & $5 \cdot 5$ & 62 & II 20 & 76 \\
\hline 8 & $4 \mathrm{I}$ & 738 & $5 \cdot 3$ & 58 & 1089 & 69 \\
\hline
\end{tabular}

Fig. 2 presents graphically the relationship between vitamin A and astaxanthin content and weight of specimen. In Fig. 3 the concentrations of vitamin A and astaxanthin have been plotted against size. The two substances measured show almost identical fluctuations.

Thysanoessa raschii. Next in importance to Meganyctiphanes norvegica as a food animal for whales in arctic krill is Thysanoessa inermis Krøyer. Because the closely related species $T$. raschii, which Einarsson (1945) regards as a fjord dweller, is available and obtained in large numbers in the same hauls as Meganyctiphanes norvegica in Loch Fyne, vitamin A was also studied in this species of euphausiid. Presence of the vitamin in high concentrations is shown in Table VIII. The ester form accounted for $95 \%$ of the total. 
The much higher concentrations of both vitamin $\mathrm{A}$ and astaxanthin in the January haul compared with the two August samples, which agree well between themselves, indicated a possible seasonal variation, but all these groups were random collections of different-sized animals, and experience

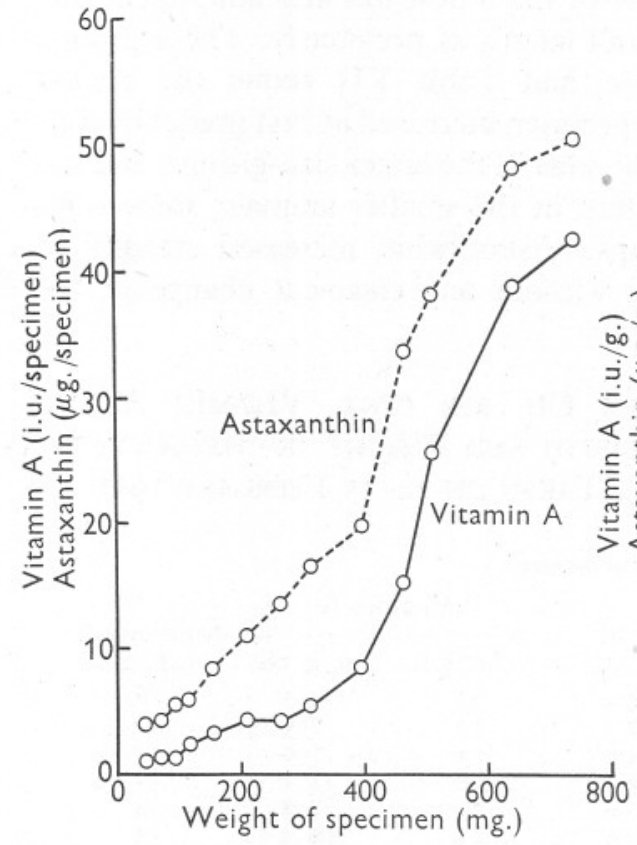

Fig. 2.

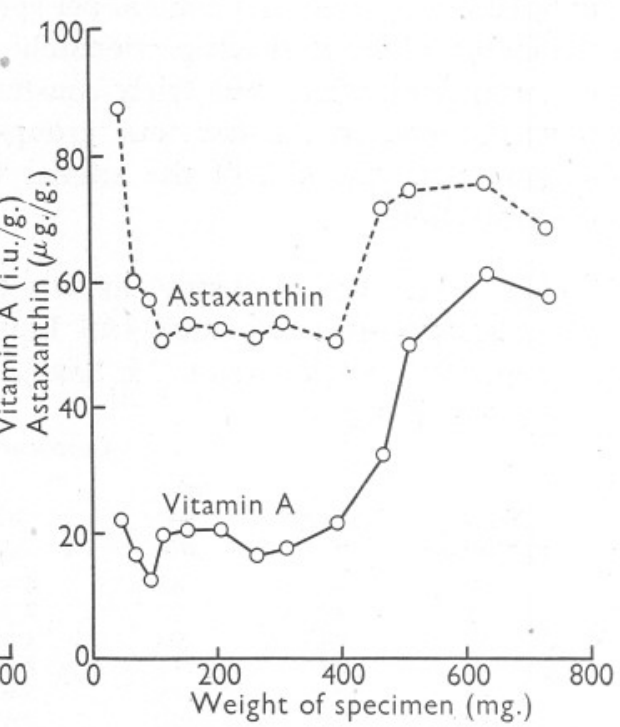

Fig. 3.

Fig. 2. Relationship between content of vitamin A and astaxanthin and size in Meganyctiphanes norvegica (M. Sars).

Fig. 3. Relationship between concentration of vitamin A and astaxanthin and size in $\mathrm{Mega}$ nyctiphanes norvegica (M. Sars).

TABle VIII. OIl PER CENT, VITAMIN A AND CAROTENOIDS PER GRAM IN THYSANOESSA RASCHII (M. SARS) FROM LOCH FyNE

( $\beta$-Carotene absent)

\begin{tabular}{|c|c|c|c|c|c|}
\hline \multirow[b]{2}{*}{ Date } & \multirow{2}{*}{$\begin{array}{l}\text { Oil } \\
(\%)\end{array}$} & \multicolumn{2}{|c|}{ Vitamin A } & \multirow{2}{*}{$\begin{array}{c}\text { Astaxanthin } \\
(\mu \mathrm{g} . / \mathrm{g} .)\end{array}$} & \multirow[b]{2}{*}{$\beta$-Carotene } \\
\hline & & (i.u./g.) & (i.u./g. oil) & & \\
\hline $\begin{array}{l}\text { 18. viii. } 49 \\
\text { 4. i. } 50\end{array}$ & $\begin{array}{l}6 \cdot 6 \\
5 \cdot 6\end{array}$ & $\begin{array}{l}32 \\
76\end{array}$ & $\begin{array}{r}495 \\
1366\end{array}$ & $\begin{array}{l}33 \\
58\end{array}$ & $\begin{array}{l}\text { Faint trace } \\
\text { Trace }\end{array}$ \\
\hline I7. viii. 50 & $6 \cdot 1$ & 32 & 520 & $3 \mathrm{I}$ & Trace \\
\hline
\end{tabular}

with Meganyctiphanes suggested that a similar relationship between vitamin A content and size might occur in Thysanoessa. T. raschii was, therefore, separated into two size-groups of less and more than $20 \mathrm{~mm}$. long, and a marked difference in vitamin A content was found, as is shown in Table IX. 
A more detailed grouping of sizes was again done as with Meganyctiphanes, with results illustrated in Table $\mathrm{X}$. With both vitamin $\mathrm{A}$ and astaxanthin the content increased with size, but the concentrations fluctuated considerably. These points are emphasized by the graphs in Figs. 4 and 5 .

Table IX. Relationship between OIl Per cent, Vitamin A and CaroTENOIDS PER GRAM AND LENGTH AND WeIGHT IN THYSANOESSA RASCHII (M. SARS)

$(\beta$-Carctene absent)

\begin{tabular}{|c|c|c|c|c|c|c|}
\hline \multirow[b]{2}{*}{ Date } & \multirow{2}{*}{$\begin{array}{l}\text { Length } \\
\text { overall } \\
\text { (cm.) }\end{array}$} & \multirow{2}{*}{$\begin{array}{l}\text { Mean } \\
\text { wt. } \\
\text { (mg.) }\end{array}$} & \multirow{2}{*}{$\begin{array}{l}\text { Oil } \\
(\%)\end{array}$} & \multicolumn{2}{|c|}{ Vitamin A } & \multirow{2}{*}{$\begin{array}{l}\text { Astaxanthin } \\
(\mu \mathrm{g} . / \mathrm{g} .)\end{array}$} \\
\hline & & & & (i.u./g.) & (i.u./g. oil) & \\
\hline 3. x. 50 & $<2$ & 27 & $7 \cdot 2$ & 60 & 833 & 43 \\
\hline 3. x. 50 & $>2$ & 52 & $10 \cdot 7$ & 83 & $78 \mathrm{I}$ & 40 \\
\hline 2 I. xi. 50 & $<2$ & 24 & 6.9 & $5 \mathrm{I}$ & 734 & 38 \\
\hline $21 . x i .50$ & $>2$ & 45 & $12 \cdot 0$ & 86 & 714 & 62 \\
\hline IO. i. $5 \mathrm{I}$ & $<2$ & 33 & $3 \cdot 0$ & 50 & I680 & 44 \\
\hline IO. i. $5 \mathrm{I}$ & $>2$ & $8 \mathrm{I}$ & 3.0 & 69 & 2293 & 46 \\
\hline
\end{tabular}

Table X. Relationship between Oil per cent, Vitamin A and CaroTENOIDS PER GRAM AND LENGTH AND WEIGHT IN THYSANOESSA RASCHII (M. SARS), TAKEN ON I4-I5 FEBRUARY I95I, IN LOCH FynE

( $\beta$-Carotene absent)

\begin{tabular}{|c|c|c|c|c|c|c|}
\hline \multirow[b]{2}{*}{$\begin{array}{c}\text { No. of } \\
\text { specimens }\end{array}$} & \multirow[b]{2}{*}{$\begin{array}{l}\text { Length* } \\
\text { (mm.) }\end{array}$} & \multirow{2}{*}{$\begin{array}{c}\text { Mean } \\
\text { wt. } \\
\text { (mg.) }\end{array}$} & \multirow[b]{2}{*}{$\begin{array}{l}\text { Oil } \\
(\%)\end{array}$} & \multicolumn{2}{|c|}{ Vitamin A } & \multirow{2}{*}{$\begin{array}{c}\text { Astaxanthin } \\
(\mu \mathrm{g} . / \mathrm{g} .)\end{array}$} \\
\hline & & & & (i.u./g.) & (i.u./g. oil) & \\
\hline 32 & II & Io & $6 \cdot 6$ & 77 & II 70 & I05 \\
\hline 309 & I3 & I8 & $3 \cdot 0$ & 84 & 2790 & 58 \\
\hline 479 & 15 & 23 & $2 \cdot 9$ & 75 & 2580 & $4 \mathrm{I}$ \\
\hline 109 & I7 & 23 & 40 & $9 \mathrm{I}$ & 2270 & 54 \\
\hline 30 & I9 & 38 & $4 \cdot 9$ & II3 & 2300 & 83 \\
\hline 29 & $2 \mathrm{I}$ & 55 & 5.9 & 100 & I690 & 37 \\
\hline
\end{tabular}

Thysanoessa inermis. In hauls taken with $\mathrm{I} \mathrm{m}$. coarse silk nets at depths of 0,20 and $100 \mathrm{~m}$. in the Sandy Bank area $\left(6 \mathrm{I}^{\circ} 54^{\prime} \mathrm{N} ., 5^{\circ} 45^{\prime}\right.$ W. $)$ at II p.m., 6 November 1950, specimens of $T$. inermis were present in the tow-nets along with those of Meganyctiphanes norvegica already mentioned. The specimens were small, with a maximum length of $15 \mathrm{~mm}$. in a species which, according to Einarsson (1945), reaches up to $32 \mathrm{~mm}$. The analytical results are shown in Table XI.

Vitamin A was present in one group in concentrations comparable with those in Thysanoessa raschii. The most significant feature of these results, however, was that the oil content increased markedly with the depth from which the specimens were taken, irrespective of their size as shown by weight and, more interesting still, the vitamin A content and concentration also increased in a similar fashion. The content of astaxanthin, on the other hand, did not appear to be related to the depth. In Meganyctiphanes norvegica, 


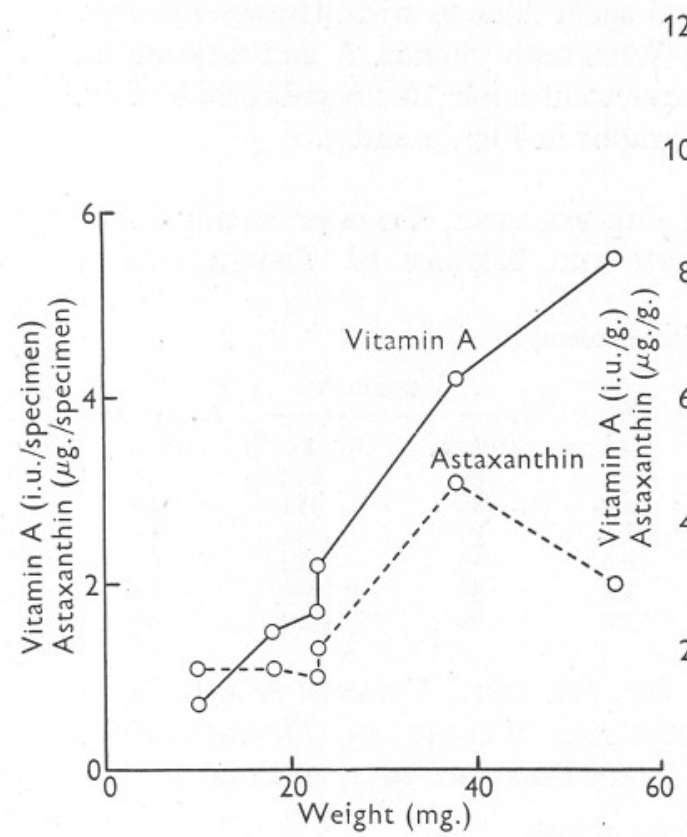

Fig. 4.

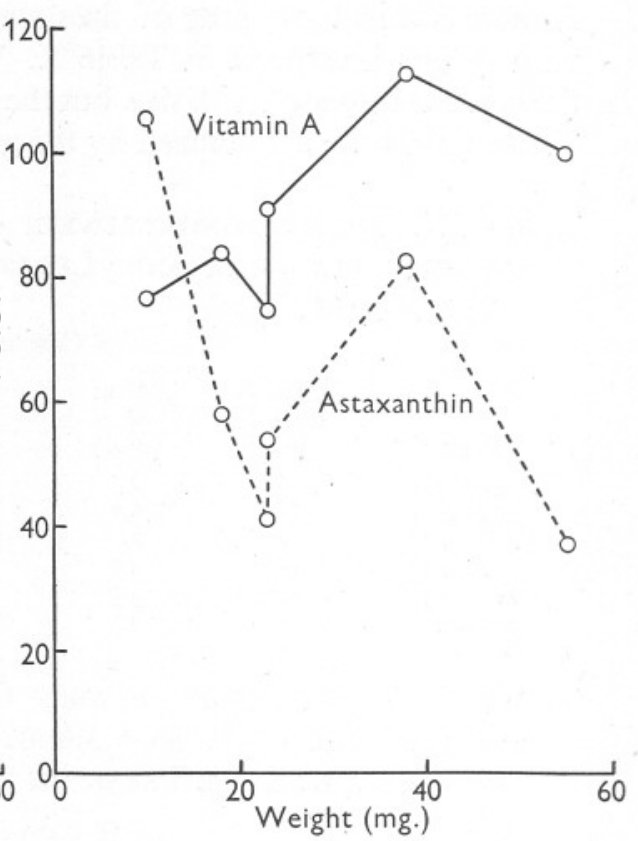

Fig. 5 .

Fig. 4. Relationship between content of vitamin A and astaxanthin and size in Thysanoessa raschii (M. Sars).

Fig. 5. Relationship between concentration of vitamin A and astaxanthin and size in Thysanoessa raschii (M. Sars).

Table XI. Oil per cent, Vitamin A and Carotenoids per gram IN THYSANOESSA INERMIS KRøYER AND MEGANYCTIPHANES NORVEGICA (M. Sars) in Relation to Depth of Haul

( $\beta$-Carotene absent)

\begin{tabular}{|c|c|c|c|c|c|c|}
\hline \multirow{2}{*}{$\begin{array}{l}\text { Depth } \\
\text { (m.) }\end{array}$} & \multirow[b]{2}{*}{$\begin{array}{l}\text { No. of } \\
\text { specimens }\end{array}$} & \multirow{2}{*}{$\begin{array}{c}\text { Mean } \\
\text { wt. } \\
\text { (mg.) }\end{array}$} & \multirow{2}{*}{$\begin{array}{l}\text { Oil } \\
(\%)\end{array}$} & \multicolumn{2}{|c|}{ Vitamin A } & \multirow{2}{*}{$\begin{array}{l}\text { Astaxanthin } \\
(\mu \mathrm{g} . / \mathrm{g} .)\end{array}$} \\
\hline & & & & (i.u./g.) & (i.u./g. oil) & \\
\hline \multicolumn{7}{|c|}{ Thyanoessa inermis } \\
\hline 0 & 374 & 8 & $5 \cdot 2$ & $5 \cdot 7$ & Iro & 73 \\
\hline 20 & 253 & II & 8.3 & 12 & I 48 & 66 \\
\hline 100 & I 24 & 7 & 12 & 55 & 474 & 86 \\
\hline \multicolumn{7}{|c|}{ Meganyctiphanes norvegica } \\
\hline 0 & 9I & 80 & 3.9 & I6 & 4107 & 65 \\
\hline 20 & 200 & 100 & $5 \cdot 6$ & I9 & 343 & 57 \\
\hline 100 & 225 & 100 & $4 \cdot I$ & I6 & $38 \mathrm{I}$ & 55 \\
\hline
\end{tabular}


taken in the same hauls with Thysanoessa inermis, no relationship was evident between content of vitamin A or oil and the depth. The results with T. inermis are, so far, only for an isolated set, but indicate that further investigation of a possible relationship between depth of haul and vitamin A content in this species may prove extremely interesting.

\section{Benthic and Littoral Eucarida}

So that comparisons with the Euphausiacea might be made, members of the other order of the subclass Eucarida, the Decapoda, were studied. Some of these animals were taken from the sea-bottom in the areas of Loch Fyne from which the euphausiids were obtained, and others were from shallower waters of this and other coasts. Details of the species studied and the results of analyses are given in Table XII.

The concentration of vitamin A was considerably less than anything found in the Euphausiacea, although in some of the larger animals, such as Portunus, Pandalus, and Nephrops, the vitamin content of individuals was on a scale comparable with that found in single specimens of Meganyctiphanes and Thysanoessa. Crangon allmani, Pandalus bonnieri and Spirontocaris spinus were all taken from depths of $140 \mathrm{~m}$. with an Agassiz trawl in waters from which large numbers of Meganyctiphanes and Thysanoessa were caught in a I m. stramin net attached to the warp of the trawl about $10 \mathrm{~m}$. above it. The figures for total carotenoids are given as such rather than for astaxanthin, since in some instances other pigments were present but were not isolated and identified. The concentration of carotenoids was lower than that of astaxanthin in the euphausiids, although larger species again showed high individual contents. $\beta$-Carotene was present in measurable quantities in oil extracted from Eupagurus and Portunus.

\section{Other Crustacea}

Pelagic Crustacea taken in the same hauls with Meganyctiphanes and Thysanoessa in Loch Fyne were the copepods, Calanus finmarchicus (Gunnerus) and Euchaeta norvegica Boeck. These were obtained on several occasions in sufficient quantities for vitamin A analysis. Other Crustacea also examined were the copepod, Euchaeta barbata Brady, which was taken during a deep oblique haul with a I m. silk net at midday on 7 November I950, in the Faeroe-Shetland channel ( $6 \mathrm{I}^{\circ} 28^{\prime} \mathrm{N} ., 3^{\circ} 42^{\prime} \mathrm{W}$.) with $\mathrm{I} 600 \mathrm{~m}$. of warp out at a sounding of $1200 \mathrm{~m}$.; the cladoceran, Evadne nordmanni Lovén, taken off the Norwegian coast, near Bergen; the littoral amphipod, Gammarus marinus Leach; and the isopod, Orchomenella nana (Krøyer), of which many were found feeding in the carapace of a dead crab. Table XIII shows the results obtained from examinations of these species.

Lederer (I938) examined Calanus caught at the end of May off the north coast of Norway and found no vitamin A in it. The results given in the table 
Table XiI. Oil per cent, Vitamin A and Carotenoids per gram in some Decapods

\begin{tabular}{|c|c|c|c|c|c|c|c|c|c|c|c|}
\hline \multirow[b]{2}{*}{ Species } & \multirow[b]{2}{*}{ Date } & \multirow[b]{2}{*}{ Locality } & \multirow[b]{2}{*}{$\begin{array}{c}\text { Oil } \\
(\%)\end{array}$} & \multicolumn{3}{|c|}{ Vitamin A } & \multicolumn{3}{|c|}{ Total carotenoids } & \multicolumn{2}{|c|}{$\beta$-Carotene } \\
\hline & & & & $\begin{array}{l}\text { (i.u./ } \\
\text { specimen) }\end{array}$ & (i.u./g.) & $\begin{array}{l}\text { (i.u. } / \mathrm{g} \\
\text { oil) }\end{array}$ & $\begin{array}{l}\text { ( } \mu \mathrm{g} . / \\
\text { specimen) }\end{array}$ & $(\mu \mathrm{g} . / \mathrm{g})$. & $\underset{\text { oil })}{(\mu \mathrm{g} . / \mathrm{g} .}$ & ( $\mu \mathrm{g} . / \mathrm{g})$. & ( $\mu$ g./g. oil) \\
\hline \multirow[t]{2}{*}{ Crangon allmani Kinahan } & $\begin{array}{l}\text { 31. viii. } 49 \\
\text { 21. xi. } 50\end{array}$ & $\begin{array}{l}\text { Loch Fyne } \\
\text { Loch Fyne }\end{array}$ & $\begin{array}{l}\mathrm{I} \cdot 3 \\
\mathrm{I} \cdot 6\end{array}$ & $\begin{array}{l}0.5 \\
0.3\end{array}$ & $\begin{array}{l}0.4 \\
0.4\end{array}$ & $\begin{array}{l}30 \\
23\end{array}$ & $\begin{array}{l}7 \cdot 0 \\
2 \cdot 7\end{array}$ & $\begin{array}{l}5.0 \\
3.8\end{array}$ & $\begin{array}{l}390 \\
238\end{array}$ & 二 & $\begin{array}{l}\text { Trace } \\
\text { None }\end{array}$ \\
\hline & I5. ii. $5 \mathrm{I}$ & Loch Fyne & $\mathrm{I} \cdot 7$ & 0.7 & 0.7 & $4 \mathrm{I}$ & $5 \cdot 3$ & $\begin{array}{l}3.0 \\
5.5\end{array}$ & 324 & - & None \\
\hline Crangon vulgaris $\mathrm{L}$. & 28. vii. 49 & $\begin{array}{l}\text { Bay of Holland, } \\
\text { Stronsay, Orkneys }\end{array}$ & 0.8 & & 0.2 & $2 \mathrm{I}$ & 33 & 5.0 & $\begin{array}{l}324 \\
550\end{array}$ & 二 & Trace \\
\hline Eupagurus bernhardus (L.) & II. xii. 50 & Burnham-on-Crouch & $\mathrm{I} \cdot 3$ & $I \cdot 2$ & 0.2 & 15 & 240 & $4 \mathrm{I}$ & 3170 & $4 \cdot 8$ & 369 \\
\hline Nephrops norvegicus L. & 13. ii. $5 \mathrm{I}$ & Loch Fyne & 0.6 & $7 \cdot 7$ & 0.04 & $7 \cdot 3$ & 1850 & II & 1800 & 0.02 & 3.8 \\
\hline \multirow{5}{*}{$\begin{array}{l}\text { Pandalus bonnieri Caullery } \\
\text { Portunus puber (L.) } \\
\text { Spirontocaris spinus (Sowerby) }\end{array}$} & 30. viii. 49 & Loch Fyne & $2 \cdot 3$ & 8.9 & $2 \cdot I$ & $89^{\circ}$ & IOI & 24 & 1000 & - & Faint trace \\
\hline & I5. ii. $5 \mathrm{I}$ & Loch Fyne & $I \cdot 6$ & $7 \cdot 2$ & I.5 & 94 & 225 & 46 & 2850 & & None \\
\hline & 4. i. 50 & Loch Fyne & 0.8 & 28 & 0.3 & 39 & 2150 & 24 & 3100 & $2 \cdot 8$ & 350 \\
\hline & 3i. viii. 49 & Loch Fyne & $2 \cdot 9$ & 0.8 & 0.6 & 22 & 34 & 27 & 950 & - & Trace \\
\hline & I5. ii. 5I & Loch Fyne & & I.O & $I \cdot I$ & 79 & 24 & 28 & 1970 & 一 & None \\
\hline
\end{tabular}

\section{Table XIII. OIl per cent, Vitamin A and Carotenoids Per gram in some Entomostraca and Peracarida}

Vitamin A absent, save in Euchaeta norvegica, 4 January and I7 August, 0.3 i.u., with 2 and I2 i.u./g. oil.

\begin{tabular}{|c|c|c|c|c|c|c|c|}
\hline \multirow{5}{*}{$\begin{array}{l}\text { Species } \\
\text { Calanus finmarchicus (Gunnerus) }\end{array}$} & \multirow{2}{*}{$\begin{array}{l}\text { Date } \\
\text { (1950) }\end{array}$} & \multirow[b]{2}{*}{ Locality } & \multirow{2}{*}{$\begin{array}{l}\text { Oil } \\
(\%)\end{array}$} & \multicolumn{2}{|c|}{ Total carotenoids } & \multicolumn{2}{|c|}{$\beta$-Carotene } \\
\hline & & & & ( $\mu \mathrm{g} . / \mathrm{g})$. & ( $\mu$ g./g. oil) & ( $\mu \mathrm{g} . / \mathrm{g})$. & ( $\mu$ g./g. oil) \\
\hline & 4. i & Loch Fyne & $\mathrm{I} \cdot 6$ & 7 & 420 & - & Trace \\
\hline & I7. iv & Loch Fyne & $2 \cdot 0$ & 18 & 970 & O.I & 7 \\
\hline & 26. vi & Near Norwegian coast & $6 \cdot 2$ & 57 & 918 & - & None \\
\hline & 4. $x$ & Loch Fyne & $7 \cdot 9$ & 24 & $33 \mathrm{I}$ & - & None \\
\hline & 7. $x i$ & Faeroe-Shetland channel & $9 \cdot 5$ & 12 & 122 & - & None \\
\hline Euchaeta norvegica Boeck & $4 . \mathrm{i} \ldots$ & Loch Fyne & II & 107 & 1000 & $\mathrm{I} \cdot 3$ & 12 \\
\hline & I7. viii & Loch Fyne & $2 \cdot 7$ & 21 & 770 & - & None \\
\hline & $3 \cdot x$ & Loch Fyne & II & 73 & 642 & - & None \\
\hline & 5. iv $v^{\star}$ & Loch Fyne & $5 \cdot \mathrm{I}$ & 19 & 367 & - & None \\
\hline Euchaeta barbata Brady & $7 \cdot x i$ & Faeroe-Shetland channel & Io & 72 & 693 & - & None \\
\hline Evadne nordmanni Lovén & 5. vi & Near Norwegian coast & $\circ$ & 0 & 0 & - & None \\
\hline Gammarus marimus Leach & 18. ix & Essex coast & $2 \cdot I$ & 35 & 1660 & - & Trace \\
\hline Orchomenella nana (Krøyer) & I0. $\mathrm{x}$ & Burnham-on-Crouch & $\mathrm{I} \cdot 4$ & I3 & 922 & - & Faint trace \\
\hline
\end{tabular}


provide a confirmation and extension of this observation, since the samples were taken at other seasons and from different places, and show that vitamin A is permanently absent from this species.

The first two extracts of Euchaeta norvegica, taken in January and August, from hauls weighing 56 and $26 \mathrm{~g}$. respectively, contained measurable quantities of vitamin A, since they gave, after chromatography, a good blue colour with antimony trichloride, but subsequent samples, taken in October and April and weighing 59 and $26 \mathrm{~g}$., did not. In those specimens in which vitamin A was present, the concentration was, however, small (Table XIII). The oil content and total carotenoid concentration also fluctuated to a considerable extent, and more seasonal data are necessary to obtain a clear picture. The large deep-sea species, E. barbata, gave similar results to those obtained with the seasonally nearest sample of $E$. norvegica, namely, that taken on 3 October 1950.

Evadne nordmanni contained no detectable vitamin $\mathrm{A}$ in the quantity examined, but information is lacking as to weight or numbers of this sample. 556 specimens of Gammarus marinus, weighing I4 g., produced no reaction for the vitamin, nor did $4 \mathrm{~g}$. of the carrion feeder, Orchomenella nana.

\section{Anatomical Distribution of Vitamin A and Carotenoids}

Concurrently with studies of the quantitative aspects of vitamin A and carotenoids in marine Crustacea, attempts were also made to determine whether these substances were locally concentrated or diffusely distributed throughout the tissues of the animals. The first dissection was crude. Cooked prawns (Leander serratus (Pennant)) from the fishmonger were divided into exoskeleton, cephalothorax and abdomen. Results of analyses showed a vitamin A concentration in the exoskeleton of 4.8 i.u./g.; in the cephalothorax, 0.4 i.u./g.; and in the abdomen, $0 . \mathrm{I}$ i.u./g.

The observations of Wald (194I, I943, I945), Neilands (1947) and other workers on the presence of vitamin A in the eyes of various Crustacea, and general knowledge of its importance as a factor in the visual cycle, drew attention to the eyes as possible sites of accumulation of vitamin A. In addition, the eyes of euphausiids, which are rich in vitamin A, are bigger in relation to the rest of the animal than those of other Eucarida in which the vitamin is present in much smaller amounts. Lönnberg (1934) tested extracts from the eyes of several species of Eucarida and these gave, in every instance, a blue colour with antimony trichloride, especially intense with Meganyctiphanes norvegica. His technique, however, did not separate vitamin A and carotenoids.

Euphausiacea. At our request, Messrs Ash and Brachi, of the scientific staff of W.F.S. Balaena, divided some boiled specimens, weighing $20 \mathrm{~g}$., of Euphausia superba from the stomach of a whale into three anatomical groups, 
soft parts, exoskeleton and eyes, subsequently preserving them in alcohol. The oil was extracted from each group and tested for vitamin A. That from the soft parts contained 6 i.u./g., or $5.6 \%$ of the total vitamin A of the $20 \mathrm{~g}$. sample, that from the exoskeleton $38 \mathrm{i}$.u./g., or $27.7 \%$, and that from the eyes I000 i.u./g., or $66.7 \%$.

Separation of the eyes from the rest of the animals was then carried out in the northern euphausiids, Meganyctiphanes norvegica and Thysanoessa raschii, and the eyes contained $92-98 \%$ of the total vitamin A present in the former and $82-98 \%$ in the latter. Typical results of these experiments are

Table XiV. Distribution of Oil per cent, Vitamin A and Astaxanthin PER SPECIMEN AND PER GRAM IN WhOle ANimal (A) AND Eyes (E) OF NorThern EuphausiIDS OF DifFERENT WeIghtS

Vitamin $\mathrm{A}(V)$ and Astaxanthin $(A)$ in eyes as percentage

\begin{tabular}{|c|c|c|c|c|c|c|c|c|c|c|}
\hline \multirow[b]{2}{*}{ Tissue } & \multirow[b]{2}{*}{$\begin{array}{l}\text { Wt. } \\
\text { (mg.) }\end{array}$} & \multirow[b]{2}{*}{ Oil } & \multicolumn{3}{|c|}{ Vitamin A } & \multicolumn{3}{|c|}{ Astaxanthin } & \multicolumn{2}{|c|}{$\begin{array}{c}\text { of that in who } \\
\text { animal }\end{array}$} \\
\hline & & & $\begin{array}{l}\text { (i.u./speci- } \\
\text { men) }\end{array}$ & (i.u.) & $\begin{array}{l}\text { (i.u./g. } \\
\text { oil) }\end{array}$ & $\begin{array}{c}(\mu \mathrm{g} . / \mathrm{speci}- \\
\text { men) }\end{array}$ & ( $\mu \mathrm{g})$. & $\underset{\text { oil) }}{\text { (mg./g. }}$ & $V$ & $A$ \\
\hline \multicolumn{11}{|c|}{ Meganyctiphanes norvegica (M. Sars) } \\
\hline A & 70 & $2 \cdot 2$ & $I \cdot 2$ & I7 & 760 & $4 \cdot 2$ & 60 & $2 \cdot 7$ & - & - \\
\hline $\mathrm{E}$ & 2 & $6 \cdot 2$ & $I \cdot I$ & 717 & II, 600 & $2 \cdot 2$ & $I, 440$ & 23 & .92 & 52 \\
\hline A & 312 & 3.4 & $5 \cdot 5$ & I8 & 520 & 17 & 54 & I.6 & - & - \\
\hline $\mathrm{E}$ & 5 & $4 \cdot 7$ & $5 \cdot 4$ & $\mathrm{I}, \mathrm{I} 50$ & 24,400 & $5 \cdot 6$ & I,200 & 26 & 98 & 33 \\
\hline A & 738 & $5 \cdot 3$ & 43 & 58 & I,090 & $5 \mathrm{I}$ & 69 & $I \cdot 3$ & - & \\
\hline $\mathrm{E}$ & II & $I \cdot 0$ & 40 & 3,610 & 361,000 & I4 & 1,220 & 122 & 94 & 27 \\
\hline \multicolumn{11}{|c|}{ Thysanoessa raschii (M. Sars) } \\
\hline A & I8 & 3.0 & I. 52 & 84 & 2,790 & $I \cdot I$ & 58 & $I \cdot 9$ & - & 一 \\
\hline E & 0.5 & $8 \cdot 3$ & $\mathrm{I} \cdot 48$ & 2,740 & 33,000 & 0.8 & $I, 490$ & 18 & 97 & 73 \\
\hline A & 38 & $4 \cdot 9$ & $4 \cdot 2$ & II3 & 2,300 & $3 \cdot I$ & 83 & $\mathrm{I} \cdot 7$ & -1 & \\
\hline $\mathrm{E}$ & 0.5 & I5 & $4 \cdot I$ & 7,750 & 51,300 & $2 \cdot 5$ & 4,680 & $3 \mathrm{I}$ & 98 & $8 I$ \\
\hline A & 55 & $5 \cdot 9$ & $5 \cdot 5$ & 100 & I,690 & $2 \cdot 0$ & 37 & 0.6 & & $\dot{-}$ \\
\hline E & 0.8 & $9 \cdot 0$ & $5 \cdot 4$ & 7,000 & 77,700 & I. 5 & $I, 980$ & 22 & 98 & 75 \\
\hline
\end{tabular}

shown in Table XIV. There was no marked variation in the percentage of vitamin $\mathrm{A}$ in the eyes throughout the series of size-groups. The high concentration of vitamin A in the oil from the eyes of the larger Meganyctiphanes is particularly striking, since it may represent a content of up to $5 \%$ pure vitamin $\mathrm{A}$. It is noteworthy that a high proportion also of the total astaxanthin content of the animal is present in the eyes, the amounts being $20-50 \%$ in Meganyctiphanes and 60-80\% in Thysanoessa.

Further dissection of larger specimens of Meganyctiphanes was done in order to ascertain the location of the small portion of vitamin A not present in the eyes. The anatomical groups examined and the results derived from them are shown in Table XV. The body vitamin A appears to be about equally divided between the exoskeleton and the contents of the cephalothorax.

Decapoda. The anatomical distribution of vitamin A in the Decapoda was studied, and results obtained were similar to those given by the Euphausiacea 
although certain differences correlated with the smaller concentrations of the vitamin present were noticeable. Cooked specimens of the common lobster (Homarus vulgaris M.-E.) were examined at an early stage in this connexion, but results for the whole animals are not available, since parts suitable for human consumption had been retained by the catering firm who kindly supplied the lobsters. In particular, the hepatopancreas was absent and so results for comparison with those of Neilands (1947), who found that this organ contained about one-third of the vitamin A present in the eyes in the

Table XV. Distribution of Oil per cent, Vitamin A and Astaxanthin PER SPECIMEN AND PER GRAM IN MEGANYCTIPHANES NORVEGICA (M. SARS)

\begin{tabular}{|c|c|c|c|c|c|c|c|}
\hline & \multirow{3}{*}{$\begin{array}{l}\text { Oil } \\
(\%)\end{array}$} & \multicolumn{3}{|c|}{ Vitamin A } & \multicolumn{3}{|c|}{ Astaxanthin } \\
\hline & & $\begin{array}{l}\text { (i.u./speci- } \\
\text { men) }\end{array}$ & (i.u./g.) & $\begin{array}{l}\text { (i.u./g. } \\
\text { oil) }\end{array}$ & $\begin{array}{c}(\mu \mathrm{g} . / \mathrm{speci}- \\
\text { men) }\end{array}$ & ( $\mu \mathrm{g} . / \mathrm{g})$. & $\begin{array}{l}(\mu \mathrm{g} . / \mathrm{g} . \\
\text { oil) }\end{array}$ \\
\hline \multicolumn{7}{|c|}{ Mean wt. of specimen, $386 \mathrm{mg}$. } & \\
\hline Exoskeleton & $9 \cdot 8$ & $0.2 \mathrm{I}$ & $\mathrm{I} \cdot 3$ & I3 & I9 & I I6 & $\mathrm{I}, \mathrm{I} 80$ \\
\hline Cephalothorax contents & 34 & 0.16 & $2 \cdot 7$ & $7 \cdot 9$ & II & I87 & 545 \\
\hline Abdomen contents & $3 \cdot 3$ & 0 & 0 & 0 & $\mathrm{I} \cdot 7$ & II & 330 \\
\hline Eyes (pair) & II & $14 \cdot 3$ & 2,460 & 22,400 & II & I,950 & 17,700 \\
\hline Whole animal & Io & $14 \cdot 7$ & 38 & 376 & 43 & I I & $\mathrm{I}, \mathrm{IOO}$ \\
\hline \multicolumn{8}{|c|}{ Mean wt. of specimen, $5 \mathrm{I} 3 \mathrm{mg}$. } \\
\hline $\begin{array}{l}\text { Cephalothorax } \\
\text { exoskeleton }\end{array}$ & $6 \cdot 6$ & 0.7 & $5 \cdot 3$ & 80 & I4 & IOO & $\mathrm{I}, 520$ \\
\hline Abdomen exoskeleton & $3 \cdot I$ & 0.3 & 3.4 & I IO & 0.8 & II & 362 \\
\hline Cephalothorax contents & $9 \cdot 2$ & $0 . \overline{8}$ & $7 \cdot 8$ & 85 & $6 \cdot 6$ & 63 & 680 \\
\hline Abdomen contents & $2 \cdot I$ & 0.2 & $\mathrm{I} \cdot 2$ & 57 & 0.9 & $5 \cdot 6$ & 267 \\
\hline Eyes (pair) & $3 \cdot 4$ & 24 & 2,880 & 84,700 & 12 & I,400 & $4 \mathrm{I}, \mathrm{IOO}$ \\
\hline Whole animal & $5 \cdot I$ & 26 & 55 & I,080 & 34 & 73 & I,430 \\
\hline
\end{tabular}

American lobster (Homarus americanus), are not yet available. Results for the lobster and other decapods are given in Table XVI. Though most of these animals have vitamin A present exclusively in the eyes, Crangon allmani and Pandalus bonnieri are interesting in that the vitamin is present also in the body, in amounts comparable with those found in bodies of Meganyctiphanes of similar sizes. The great difference is in the eyes, which are relatively much smaller in the Decapoda and contain less vitamin A, the concentration in Pandalus eyes, for instance, being only about one-tenth of that in those of Meganyctiphanes. The eyes of lobsters contain about $90 \%$ of their vitamin A in the ester form, and a similar figure was obtained for the eyes of Nephrops norvegicus.

\section{Biological Tests \\ Methods}

Preparation of Material for Tests with Rats and Standards used

The method of extraction was as described earlier in this paper. The oil obtained was diluted suitably with arachis oil and given directly to rats, or 
Table XVI. Distribution of Oil per cent, Vitamin A and Carotenoids per specimen and per gram in Some Decapods

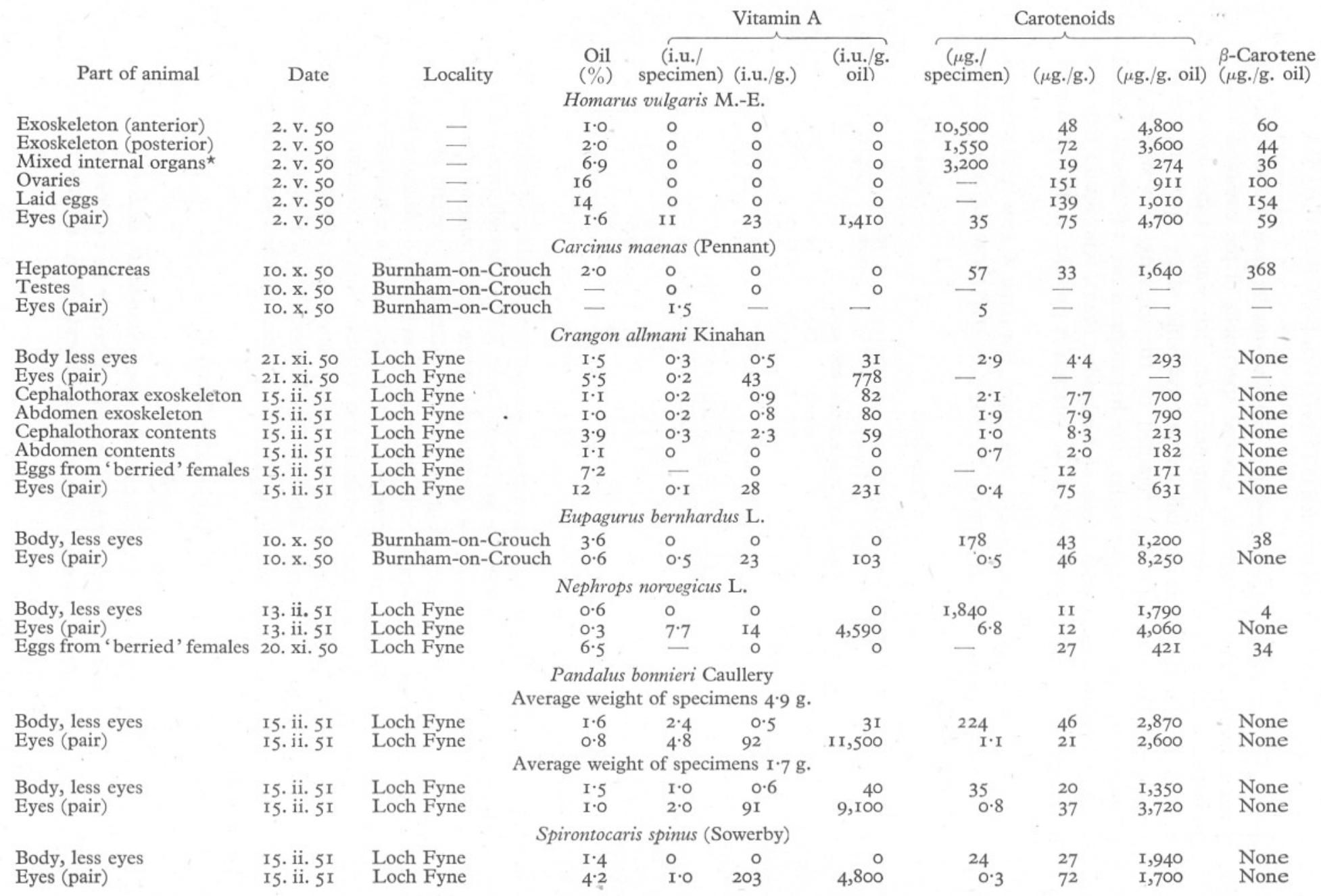

* Hepatopancreas and other edible parts absent. 
subjected to chromatography to remove the bulk of the pigments, or saponified and chromatographed as for the chemical test, and the non-saponifiable residue containing vitamin $\mathrm{A}$ in the alcohol form was diluted with arachis oil for feeding to rats. For the rat-growth tests, the oils were kept under nitrogen in the refrigerator and tested periodically for vitamin A by the Carr-Price test.

For the liver-storage test, the standard was a fish-liver oil at 106,000 i.u./g., and for the rat-growth experiments the International Standard for vitamin A at Io,000 i.u./g. in cottonseed oil was used. Both were diluted suitably for feeding with arachis oil stabilized with hydroquinine.

\section{Preparation of the Rats}

Hooded Norwegian rats of our own breeding were used. Rats partly deficient in vitamin A were prepared exactly as described by Thompson et al. (I949). It will be recalled that such rats have vitamin A neither in the liver nor in the intestine, but have not stopped growing.

To obtain rats wholly deficient in vitamin A the mothers were deprived of milk, liver and carrots, their dietary sources of vitamin A, as soon as the young were born; from the I6th day of lactation they were given our vitamin A-deficient diet (Henry, Kon, Mawson, Stanier \& Thompson, I949). The young were weaned on to this diet at $2 \mathrm{I}$ days of age and continued on it during the 'running-out' and dosing periods.

Partly deficient rats were dosed by the method described by Thompson et al. (1949), except that actual or presumptive quantities of the order of IOO, 50 and 25 i.u. of vitamin A from the standard or the oils under test were added to $400 \mathrm{mg}$. of arachis oil.

Experiment I. In a preliminary experiment, rats were given the vitamin A alcohol chromatographically separated from the non-saponifiable residue of oil obtained from krill forming the stomach contents of fin whale I (see Table II), consisting mainly of Euphausia superba. They were anaesthetized after $3 \mathrm{hr}$., and the intestinal contents were washed out in vivo; the intestinal wall and contents and the liver were then analysed as described by Thompson, Braude, Coates, Cowie, Ganguly \& Kon (I950).

Experiment 2. The non-saponifiable residue from oil of the same source as in Exp. I was diluted with arachis oil to a concentration of approximately 200 i.u./g. Three rats were used for each of three levels of standard or krill oil and were killed after $3 \mathrm{hr}$., the livers being removed for analysis.

Using wholly deficient rats the following rat-growth tests (Booth, Kon \& Gillam, 1934) were performed.

Experiment 3. Groups of eight (four of each sex) deficient rats were dosed at the rate of 2 or 4 i.u. International Standard Vitamin A daily or with the non-saponifiable residue of the body oil of Meganyctiphanes norvegica, Thysanoessa raschii and Euphausia superba; these were suitably diluted with 
arachis oil and given to the rats to supply 2 and 4 i.u. vitamin A as determined chemically. The rats were dosed twice a week.

Experiment 4. Groups of fourteen (seven of each sex) deficient rats were dosed twice weekly, at the rate of I, 2 and 4 i.u. daily with vitamin A standard or the non-saponifiable residue, dissolved in arachis oil, of the oil of Meganyctiphanes norvegica caught in Loch Fyne in January 1950.

Experiment 5. Groups of ten (five of each sex) deficient rats were used. Oil from Thysanoessa raschii, caught in Loch Fyne in January and August I950, was tested intact or after chromatographic removal of the pigment; these oils were fed undiluted at levels supplying about I, 2 and 4 i.u. vitamin A daily. The standard was also fed at these levels. Animals were dosed twice a week as in the other experiments.

\section{Results}

Experiment I. The vitamin A in the intestinal wall of the rats was largely in the ester form, while in the liver both forms of vitamin A were present in roughly equal amounts. There was no vitamin $\mathrm{A}$ in the gut contents. The behaviour of the vitamin A from krill was, therefore, exactly the same as of that formed from $\beta$-carotene or of pure vitamin $\mathrm{A}$, when given under similar conditions (cf. Thompson et al. I950).

Experiment 2. The results of this experiment are given in Table XVII. In Fig. 6 the net vitamin $A^{\star}$ stored in the liver is plotted against the dose of vitamin $\mathrm{A}$ for the standard. It will be noticed that the points lie on a straight line which does not pass through the origin. This curve can be used to estimate the potency of the krill oil by reading off, against the net liver stores of vitamin $\mathrm{A}$, the corresponding amount of vitamin $\mathrm{A}$ in each dose.

These results show a strong similarity in the behaviour of vitamin A from krill and from fish-liver oils, though naturally storage in the liver cannot be taken as a decisive biological proof of the identity of the stored substance with vitamin A.

Experiment 3. Table XVIII shows the results of this experiment and indicates that the chemical potency was two to three times higher than the biological, despite the findings that the euphausiid vitamin A was chemically and physically indistinguishable from pure vitamin A.

Experiment 4. Table XIX shows that, even with the larger number of rats used and a more satisfactory test, the chemical result was almost twice the biological.

Experiment 5. The discrepancy between the chemical and the biological potencies is again apparent in Table $\mathrm{XX}$, which also indicates that the pigments (astaxanthin) did not affect the biological activity, since there was no difference between results obtained with whole oil and those with whole oil less pigments. This also confirms biologically the absence of $\beta$-carotene or other precursors of vitamin A from the pigments.

* Net vitamin $\mathrm{A}=$ vitamin $\mathrm{A}$ stored in liver less vitamin $\mathrm{A}$ found in control livers. 
TAble XVII. Exp. 2. Vitamin A, Alcohol and Ester, AS I.U. PER ORgan, IN LIVER of PARTLy Vitamin A-DEFicient Rats DOSED WITH 0.4 G. ARACHIS Oil Containing Vitamin A from Fish-Liver Oil (B) or Krill Oil (C)

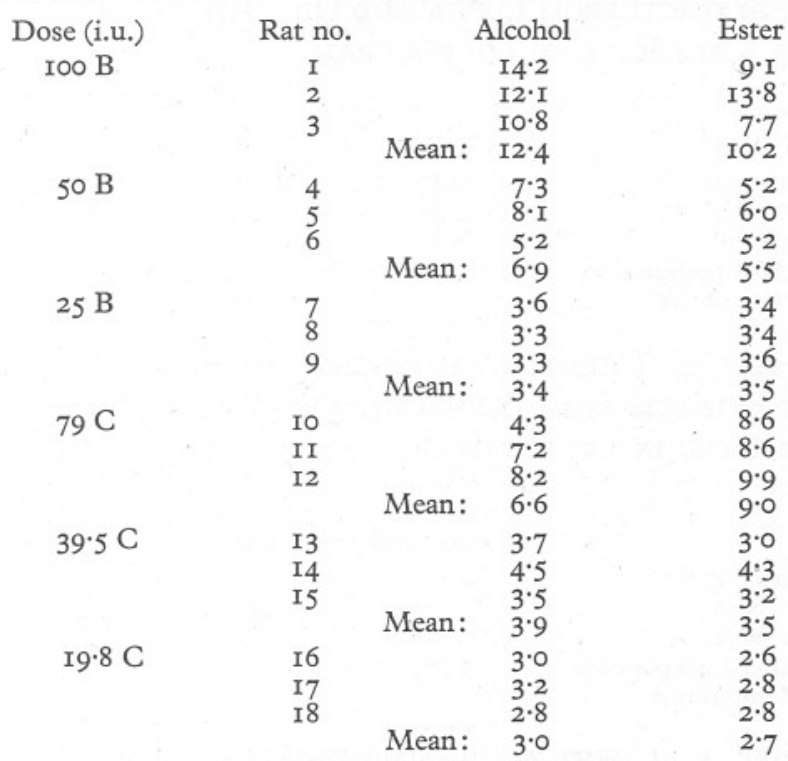

Mean for two control rats: I.O alcohol, $2 \cdot 7$ ester.

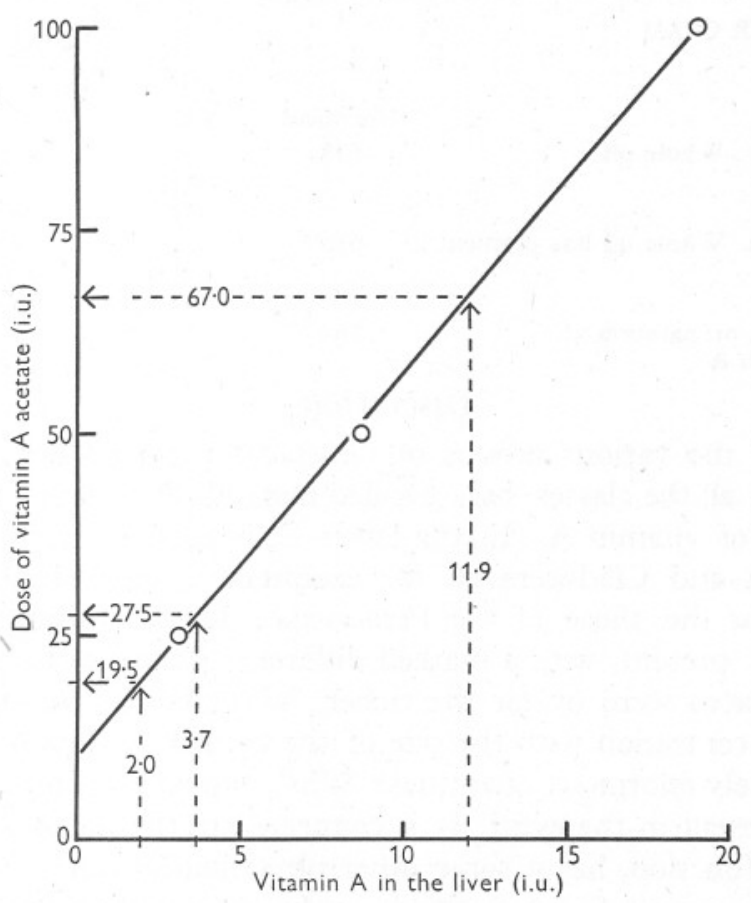

Fig. 6. Exp. 2. Liver storage tests with rats given the non-saponifiable residue of euphausiid oils. Graph showing relationship between dose of pure vitamin A acetate and vitamin A stored in the liver, and the calculation of doses of vitamin A corresponding to storage of vitamin $\mathrm{A}$ found in test rats. 
Table XVIII. Exp. 3. Chemical (antimony-trichloride) and Biological Tests on Extracts From Euphausitd Oils fed to wholly Vitamin ADEFICIENT MALE RATS, IN I.U. PER GRAM

\begin{tabular}{|c|c|c|c|}
\hline \multicolumn{3}{|c|}{ CIEN TIALE NATS, IN 1.U. PEK GK } & Biological \\
\hline & Chemical & Value & $\begin{array}{l}\text { True fiducial limits } \\
\qquad(P=0.95)\end{array}$ \\
\hline $\begin{array}{l}\text { M. norvegica } \\
\text { T. raschii } \\
\text { E. superba }\end{array}$ & $\begin{array}{l}\text { I47 } \\
\text { I48 } \\
\text { I58 }\end{array}$ & $\begin{array}{l}55 \cdot 7 \\
64 \cdot 3 \\
71 \cdot 3\end{array}$ & $\begin{array}{l}5.4 \text { to } 113.6 \\
4.5 \text { to } 227.3 \\
9.9 \text { to } 138.5\end{array}$ \\
\hline $\begin{array}{l}\text { Standard preparation } \\
\text { of vitamin A }\end{array}$ & 228 & - & - \\
\hline
\end{tabular}

Table XiX. Exp. 4. Chemical (antimony-trichloride) and Biological TESTS ON Extracts From Euphausidd Oils fED to Wholly Vitamin ADEFICIENT RATS, IN I.U. PER GRAM

\begin{tabular}{|c|c|c|c|}
\hline \multicolumn{2}{|c|}{ CIENT RATS, IN I.U. PER GRAM } & \multicolumn{2}{|r|}{ Biological } \\
\hline & Chemical & Value & $\begin{array}{l}\text { True fiducial limits } \\
\qquad(P=0.95)\end{array}$ \\
\hline M. norvegica & 378 & - & - \\
\hline ㅇ Rats & - & 234 & I53 to 390 \\
\hline ô Rats & - & 307 & 192 to 612 \\
\hline $\begin{array}{l}\text { Standard preparation } \\
\text { of vitamin A }\end{array}$ & I74 & - & - \\
\hline
\end{tabular}

Table XX. Exp. 5. Chemical (antimony-trichloride) and Biological Tests on Euphausid Oils FED to wholly Vitamin A-DEFICIENT Rats, IN I.U. PER GRAM

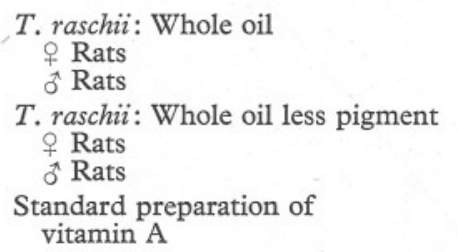

$\begin{array}{ccc}\text { Chemical } & \text { Value } & \begin{array}{c}\text { True fiducial limits } \\ (P=0.95)\end{array} \\ 678 & - & - \\ - & 333 & 204 \text { to } 632 \\ \text { 610 } & 391 & 249 \text { to } 730 \\ - & - & - \\ - & 432 & 200 \text { to } 645 \\ \text { 169 } & - & 279 \text { to } 869\end{array}$

\section{Discussion}

The study of the various groups of Crustacea reported here, though not covering so far all the classes, has revealed marked differences in content and concentration of vitamin A. In the lower Crustacea, the representatives of the Copepoda and Cladocera so far examined contained no measurable vitamin A, nor did those of the Peracarida. In the Eucarida in general vitamin A was present, with a marked difference between the two orders in that Euphausiacea were by far the richer. Why should the vitamin, rising sharply in concentration with the size of the animal, be found in this order in such relatively enormous quantities? Why, moreover, should it be almost exclusively present in the eyes? Is it connected in these animals with some special visual function, has it some other physiological duty, or are the eyes merely storage organs for something produced or accumulated in excess? 
Decapods are predominantly benthic in their habits, and perhaps in their constant contact with the sea floor they have less need for acute vision than the free-swimming euphausiids. Admittedly other free-swimming Crustacea such as copepods contain no vitamin A, but their reaction to light may be of a different character from that of euphausiids, and in any case the structure of their eyes is much simpler. In fact, the exceptionally large and prominent eyes are a characteristic feature of euphausiids which may be specially well adapted for adequate vision in the low intensity of light at the depth they frequent. It will be recalled that a large specimen of Meganyctiphanes norvegica may contain in its eyes some 40 i.u. of vitamin A, and even allowing for the special demands of this order it seems hard to believe that vitamin A is needed there in such quantities solely for the functions of vision. In Meganyctiphanes the concentration of vitamin A in the eyes is in the range 2400-I2000 i.u./g. dry weight (taking the water content as $70 \%$ ). With these figures may be compared the findings of Wald (1935) that mammalian retinas have vitamin A concentrations of about 70 i.u./g. dry weight and frog retinas have I200 i.u./g., whereas the pigmented layers of the frog eye contain 6000 i.u./g. Morton \& Rosen (I949) give results for seasonal variations of vitamin A in frog eyes. The highest value they obtained was about $3.5 \mu \mathrm{g}$./eye; in a frog of $20 \mathrm{~g}$. weight of which the eyes account for about I $\%$ this gives a vitamin A concentration of I05 i.u./g. wet weight, or approximately 300 i.u./g. on the dry basis.

We intend to investigate the distribution and anatomical location of vitamin $\mathrm{A}$ in euphausiid eyes in the hope of finding thereby something more about its purpose there. In the meantime the possibility of its being to some extent an excretory substance cannot be dismissed.

$\mathrm{Be}$ it as it may, it is evident that baleen whales can derive from krill immense quantities of vitamin $\mathrm{A}$, quite sufficient to account for the great stores of the vitamin in whale liver. According to Einarsson (1945) a large whale may have up to 12001 . of krill in its stomach. This would be roughly a ton, and with a vitamin A potency of, say, 20 i.u./g. would yield about 2,000,000 i.u.

The richness in vitamin $\mathrm{A}$ of the food of baleen whales associated with the high concentration of vitamin A in their livers may be contrasted with its lack in another crustacean, Calanus finmarchicus, and the corresponding paucity in vitamin A of animals whose principal food it forms, the herring and the basking shark.

In the euphausiids studied by us vitamin A was accompanied in the eyes by astaxanthin in high concentrations and in fact a large proportion (20-50\% in Meganyctiphanes norvegica and 60-80 \% in Thysanoessa raschii) of the total pigment of these animals was present there. The function of this characteristic pigment of Crustacea is not yet understood. Its value, if any, for the higher animals, preying on Crustacea, presents an interesting problem deserving 
further study. Thus Wald (I945) found astaxanthin in the eyes of birds; Grangaud \& Massonet (I950) report that it prevents and cures xerophthalmia in vitamin A-deficient rats, though it does not alleviate other signs of the deficiency or promote growth, and it is well possible that the pigment has some vitamin-like function. Its chemical constitution is such that it can hardly act as precursor of vitamin A itself. Furthermore, in our biological tests it proved entirely inactive in this respect. As corroborative evidence may be cited the fact that Calanus finmarchicus is at times quite rich in the pigment without apparently affecting the low vitamin A content of herring.

Again, we found no $\beta$-carotene in euphausiids, observations sharply at variance with those of Wagner (I939), who reported large quantities of $\beta$-carotene in northern krill, and we are entirely at a loss to understand how he came to detect this pigment. The finding of vitamin $\mathrm{A}$ in large quantities in certain euphausiids accounts, we hope adequately, for the immediate source of the vitamin A of the whale. It makes it also clear that baleen whales obtain most of their vitamin A as such and have no need and, indeed, no opportunity, to form it from precursors, though in common with other mammals they no doubt are able to do so. One link of a food chain is thus accounted for, but the fundamental problem of the site of origin of the vitamin A of marine organisms remains unexplained. The focus of attention has been moved from the whale to its food, and the question arises whether euphausiids in turn obtain their vitamin A preformed or whether they manufacture it themselves from precursors in their food.

Though our work on vitamin $\mathrm{A}$ in marine animals began more than two years ago, the more systematic study has been going on for little more than a year. In so short a period variations due to seasonal and other causes could be observed only in a very broad outline.

The relationship between size and vitamin A concentration in Meganyctiphanes stands out so clearly as to indicate close correlation. At first, size and content increase pari passu; with large animals the concentration also rises steeply. This may well indicate a change in food or metabolism around the weight stage of about $0.4 \mathrm{~g}$.

Our data are, so far, insufficient to indicate seasonal variations in vitamin A content of Meganyctiphanes, especially as the size of the animal exerts such marked influence, but with Thysanoessa raschii the indications are clearer that the concentration of vitamin A may be higher during the winter months. Our evidence so far is that Thysanoessa differs from Meganyctiphanes in that concentration of vitamin A does not increase with size.

The isolated observation of the relation between vitamin A content and depth of haul in Thysanoessa inermis is striking, especially since the animals were of uniform size and Meganyctiphanes taken in the same hauls, also of uniform size, did not exhibit this variation.

In the decapods studied vitamin A was also largely concentrated in the eyes, 
though in some species, of which Crangon allmani is the notable example, at least half of the vitamin was present in other parts of the body. We do not know yet whether in these anima's it was adventitious in the alimentary canal or as a true constituent. We are also in a similar doubt about the small quantity of vitamin A found in euphausiids not in the eyes.

The values quoted for vitamin A throughout this paper are those derived from chemical and physical measurements. We are satisfied that these were done with the necessary care and after adequate purification and separation, but we are aware that so far all our biological tests have indicated a potency lower than that of corresponding laboratory measurements. This difference exists for all species studied regardless of the purity of the preparations fed, and suggests either the presence of growth-inhibiting substances closely associated with the vitamin A fraction or the presence in these purified fractions of chemically related substances giving rise to an artefact.

The work described in this paper has been supported by a grant from the Development Commission. Its success so far has largely depended on the ready assistance given by many people engaged in marine biological work and in the whaling industry, whom we have from time to time visited either for discussion or for the use of facilities they control. The unique facilities for collecting euphausiids in Loch Fyne have meant that the Marine Station at Millport has had much more than a fair share of our visits, and we are extremely grateful to $\mathrm{Mr}$ E. Ford and his staff, especially Drs S. M. Marshall, A. P. Orr and D. T. Gauld, for all their help and forbearance. We must also mention Dr C. E. Lucas and his staff at the Fisheries Laboratory, Aberdeen; Dr J. A. Lovern of the Torry Research Station, Aberdeen; Dr J. G. Sharp of the Low Temperature Research Station, Cambridge; Messrs Blomvåg Hval, their manager, Mr A. Hojem and Capt. H. Harneshaug of their catcher, Hval 2, in Norway; Messrs Scottish Whalers Ltd., and their manager, Capt. H. Jespersen, at West Loch, Tarbert, Harris; Messrs United Whalers Ltd. and their chemists, Mr C. E. Ash and Mr R. M. Brachi, of W.F.S. Balaena; Messrs M. Graham and R. S. Wimpenny of the Fisheries Laboratory, Lowestoft; Mr F. S. Russell and his staff at the Marine Laboratory, Plymouth; Mr R. D. Waugh and his staff at the Oyster Research Station, Burnham-on-Crouch; Drs N. A. Mackintosh and H. Bargmann and Mr R. Clarke and other members of the staff of the Discovery Investigations; Prof. C. H. O'Donoghue, Dr N. B. Eales and Mr M. I. Crichton of Reading University; and Dr E. B. Hughes and Mr D. H. F. Clayson of Messrs Lyons' Laboratories, Hammersmith.

We are deeply grateful to our colleague, Dr K. M. Henry, for the biological tests on rats, and we gladly acknowledge the collaboration of Miss I. E. Batham, M.H.Sc. (N.Z.), who took part in certain aspects of the study while on leave of absence from Otago University. We have had much analytical assistance from Miss W. M. Vardy. 


\section{SUMMARY}

Planktonic, benthic and littoral Crustacea were collected from localities around the British coast, from Norwegian and Faeroese waters and from the Antarctic, and their content of preformed vitamin A and carotenoid pigments was measured.

Methods are described for the preservation of specimens, the extraction and separation of vitamin $\mathrm{A}$ and carotenoids and the measurement of vitamin $\mathrm{A}$ by chemical, physical and biological tests, and of carotenoids by physical tests.

Free-swimming euphausiids were found to contain, in addition to large quantities of astaxanthin, high concentrations of preformed vitamin $\mathrm{A}$, but no $\beta$-carotene.

Krill, taken from the stomachs of whales, consisting of Meganyctiphanes norvegica in arctic waters and Euphausia superba in antarctic waters, also contained no $\beta$-carotene, but preformed vitamin A was present, although in lower concentrations than in free-swimming animals.

In Meganyctiphanes norvegica, the vitamin A concentration increased with the size of the animal, but in Thysanoessa raschii it was unchanged. In both species, the astaxanthin content, but not concentration, was higher in the larger animals.

The eyes of the euphausiids contained over $90 \%$ of their total vitamin A, the rest being in the exoskeleton and contents of the cephalothorax. A high proportion of the total astaxanthin was also in the eyes.

The vitamin A concentration was much lower in the decapods, the difference being in the eyes, since their bodies contained the vitamin in quantities comparable to those found in the bodies of euphausiids.

Vitamin A was absent from the amphipods, isopods and Cladocera examined. In the Copepoda, Calanus finmarchicus was devoid of the vitamin, but it was present in small quantities in some samples of Euchaeta norvegica.

Biological tests with rats on oils or concentrates from euphausiids indicated potencies about one-half those expected from results of chemical and physical tests. The pigments showed no biological activity.

It is suggested that the high vitamin A content of euphausiids forming the food of whales is adequate to account for the rich liver stores of the vitamin in those mammals.

\section{REFERENCES}

Batham, E., Fisher, L. R., Henry, K. M., Kon, S. K. \& Thompson, S. Y., I95I. Preformed vitamin A in marine Crustacea. Biochem. Fourn., Vol. 48, p. x.

Bоoth, R. G., Kon, S. K. \& GILlAM, A. E., I934. The relative biological efficiencies of the vitamin A and carotene of butter. Biochem. fourn., Vol. 28, pp. 2169-74.

Collin, G., Drummond, J. C., Hilditch, T. P. \& GunTher, E. R., I934. Observations on the fatty constituents of marine plankton. II. General character of the plankton oils. Fourn. Exp. Biol., Vol. I I, pp. 198-202. 
Drummond, J. C. \& GUNTHER, E. R., I930. Vitamin content of marine plankton. Nature, Lond., Vol. I26, p. 398.

- I934. Observations on the fatty constituents of marine plankton. III. The vitamin $\mathrm{A}$ and $\mathrm{D}$ content of oils derived from plankton. fourn. Exp. Biol., Vol. II, pp. 203-9.

Drummond, J. C. \& Hilditch, T. P., I930. The relative values of cod-liver oils from various sources. E.M.B. [Publ.] No. 35, pp. I-I29.

Drummond, J. C. \& MacWalter, R. J., I935. Pro-vitamin A in the food of whales. fourn. Exp. Biol., Vol. 12, pp. 105-7.

EINARsson, H., I945. Euphausiacea. I. Northern Atlantic species. Dana Report No. $27, \mathrm{I} 85 \mathrm{pp}$.

Fisher, L. R., Kon, S. K. \& Thompson, S. Y., I95I. Distribution of vitamin A in the organs of marine Crustacea. Biochem. Fourn., Vol. 49, p. xv.

Gillam, A. E., El Ridi, M. S. \& WimpenNy, R. S., I939. The seasonal variation in biological composition of certain plankton samples from the North Sea in relation to their content of vitamin A, carotenoids, chlorophyll, and total fatty matter. fourn. Exp. Biol., Vol. I6, pp. 7 I-88.

Goodwin, T. W. \& SRIsukh, S., I949. The biochemistry of locusts. I. The carotenoids of the integument of two locust species (Locusta migratoria migratorioides R. \& F. and Schistocerca gregaria Forsk.). Biochem. Fourn., Vol. 45, pp. $263-8$.

Grangaud, R. \& Massonet, R., I950. Activité antixérophtalmique du pigment caroténoïde d'Aristeomorpha foliacea (Penaeidae). C.R. Acad. Sci., Paris, T. 230, pp. I3I9-2I.

Henry, K. M., Kon, S. K., Mawson, E. H., Stanier, J. E. \& Thompson, S. Y., 1949. The passage of vitamin A from mother to young in the rat. Brit. Fourn. Nutrit., Vol. 3, pp. 301-I9.

HJoRT, J., I922. Observations on the distribution of fat-soluble vitamins in marine animals and plants. Proc. Roy. Soc. B, Vol. 93, pp. 440-9.

Kon, S. K. \& Thompson, S. Y., I949a. Preformed vitamin A in Crustacea. Arch. Biochem., Vol. 24, pp. 233-4.

—_ I949b. Preformed vitamin A in northern krill. Biochem. Fourn., Vol. 45, p. xxxi.

- I95I. Site of conversion of carotene to vitamin A. Brit. Fourn. Nutrit., Vol. 5, pp. I I4-I9.

Lederer, E., I938. Recherches sur les caroténö̈des des invertébrés. Bull. Soc. Chim. Biol., Paris, T. 20, pp. 567-610.

LöNNBERG, E., I934. On the occurrence of carotenoid pigments in the eyes of certain animals. Ark. Zool., Bd. 28A, No. 4, pp. I-I4.

Macdonald, R., I927. Food and habits of Meganyctiphanes norvegica. Fourn. Mar. Biol. Assoc., Vol. I4, pp. 753-8r.

Morton, R. A. \& Rosen, D. G., I949. Carotenoids, vitamin A and 7-dehydrosteroid in the frog (Rana temporaria). Biochem. Fourn., Vol. 45, pp. 6I2-27.

NeILANDS, J. B., I947. The conversion of carotene to vitamin A in the fish. Arch. Biochem., Vol. 13, pp. 415-I9.

Pugsley, L. I., I94I. The nutritive value of marine products. XV. Proximate analyses of canned British Columbia crabs, shrimps and clams. Fourn. Fish. Res. Bd., Canada, Vol. 5, pp. 344-6.

Thompson, S. Y., I949. A photoelectric spectrophotometer suitable for the measurement of vitamin A by the antimony-trichloride reaction. Brit. Fourn. Nutrit., Vol. 3, pp. 43-50. 
Thompson, S. Y., Braude, R., Coates, M. E., Cowie, A. T., Ganguly, J. \& Kon, S. K., I950. Further studies of the conversion of $\beta$-carotene to vitamin $A$ in the intestine. Brit. Fourn. Nutrit., Vol. 4, pp. 398-42I.

Thompson, S. Y., Ganguly, J. \& Kon, S. K., I947. The intestine as a possible seat of conversion of carotene to vitamin $\mathrm{A}$ in the rat and the pig. Brit. Fourn. Nutrit., Vol. I, pp. v-vi.

I949. The conversion of $\beta$-carotene to vitamin $\mathrm{A}$ in the intestine. Brit. Fourn. Nutrit., Vol. 3, pp. 50-78.

WAGNER, K.-H., I939. Vitamin A und $\beta$-Carotin des Finn-, Blau- und Spermwals. Leipzig. $70 \mathrm{pp}$.

WaLD, G., I935. Vitamin A in eye tissues. Fourn. Gen. Physiol., Vol. I8, pp. 905-I5. I94I. Vitamin A in invertebrate eyes. Amer. Fourn. Physiol., Vol. I33, p. 479. 1943. The photoreceptor functions of the carotenoids and vitamins A. Vitamins \& Hormones, Vol. I, pp. 195-228.

- I945. The chemical evolution of vision. Harvey Lect., ser. 4I, pp. II7-60. 